\title{
38. CONTENT, TYPE, AND THERMAL EVOLUTION OF ORGANIC MATTER IN SEDIMENTS FROM THE EASTERN FALKLAND PLATEAU, DEEP SEA DRILLING PROJECT, LEG 71 ${ }^{1}$
}

\author{
Hans von der Dick, ${ }^{2}$ Lehrstuhl für Geologie, Geochemie und Lagerstätten des Erdöls und der Kohle, \\ Rheinisch-Westfälische Technische Hochschule, Aachen, D-5100 Aachen, Federal Republic of Germany \\ and \\ Jurgen Rullkötter and Dietrich H. Welte, Institut für Erdöl und Organische Geochemie (ICH-S) \\ Kernforschungsanlage Jülich GmbH, D-5170 Jülich, Federal Republic of Germany
}

\begin{abstract}
The quantity, type, and maturity of the organic matter in Recent through Upper Jurassic sediments from the Falkland Plateau, DSDP Site 511, have been determined. Sediments were investigated for their hydrocarbon potential by organic carbon and Rock-Eval pyrolysis. Kerogen concentrates were prepared and analyzed in reflected and transmitted light to determine vitrinite reflectance and maceral content. Total extractable organic compounds were analyzed for their elemental composition, and the fraction of the nonaromatic hydrocarbons was determined by capillary column gas chromatography and combined gas chromatography/mass spectrometry.

Three main classes of organic matter can be determined at DSDP Site 511 by a qualitative and quantitative evaluation of microscopic and geochemical results. The Upper Jurassic to lower Albian black shales contain high amounts of organic matter of dominantly marine origin. The content of terrigenous organic matter increases at the base of the black shales, whereas the shallowest black shales near the Aptian/Albian boundary are transitional in composition, with increasing amounts of inert, partly oxidized organic matter which is the dominant component in all Albian through Tertiary sediments investigated.

The organic matter in the black shales has a low level of maturity and has not yet reached the onset of thermal hydrocarbon generation. This is demonstrated by the low amounts of total extractable organic compounds, low percentages of hydrocarbons, and the pattern and composition of nonaromatic hydrocarbons. The observed reflectance of huminite and vitrinite particles (between $0.4 \%$ and $0.5 \% \bar{R}_{0}$ at bottom-hole depth of $632 \mathrm{~m}$ ) is consistent with this interpretation. Several geochemical parameters indicate, however, a rapid increase in the maturation of organic matter with depth of burial. This appears to result from the relatively high heat flow observed at Site 511. If we relate the level of maturation of the black shales at the bottom of Hole 511 to their present shallow depth of burial, they appear rather mature. On the basis of comparisons with other sedimentary basins of a known geothermal history, a somewhat higher paleotemperature gradient and/or additional overburden are required to give the observed maturity at shallow depth.

A comparison with contemporaneous sediments of DSDP Site 361, Cape Basin, which was the basin adjacent and to the north of the Falkland Plateau during the early stages of the South Atlantic Ocean, demonstrates differences in sedimentological features and in the nature of sedimentary organic matter. We interpret these differences to be the result of the different geological settings for Sites 361 and 511 .
\end{abstract}

\section{INTRODUCTION}

DSDP Site $511\left(51^{\circ} 00.28^{\prime} \mathrm{S} ; 46^{\circ} 58.30^{\prime} \mathrm{W}\right)$ was drilled during Leg 71 in the basin province of the Falkland Plateau about $10 \mathrm{~km}$ south of DSDP Site 330 (Leg 36) at a water depth of 2589 meters.

About 630 meters of sediments of Recent to Late Jurassic age were penetrated and divided into six major lithostratigraphic units (site chapter, this volume). A major unconformity of about $25 \mathrm{~m}$.y. separates the Tertiary and the Cretaceous sediments. Small layers of midCretaceous black shales were first encountered in Core 56 at a sediment depth of 495 meters. Drilling into the black shales was terminated at a sub-bottom depth of 632 meters, after increasing amounts of gaseous hydrocarbons with low $\mathrm{C}_{1} / \mathrm{C}_{2}, \mathrm{C}_{2} / \mathrm{C}_{3}$, and $\mathrm{C}_{2} / \mathrm{C}_{5}$ hydrocarbon ratios were detected and a strong seismic reflector at a sub-bottom depth of 700 meters was observed.

Our study is concerned with the content, type, and thermal maturation of organic matter in the sediments

\footnotetext{
${ }^{1}$ Ludwig, W. J., and Krasheninnikov, V. A., et al., Init. Repts. DSDP, 71: Washington (U.S., Govt. Printing Office).

2 Present address: Petro Canada Research Laboratory, 40 Research Place NW, Calgary, Alberta, Canada.
}

at DSDP Site 511. Investigation of the type and quantity of organic matter will provide information about the environmental conditions in the early South Atlantic Ocean and thus contribute to one of the major objectives of this leg-understanding the paleoceanographic conditions of the South Atlantic.

In addition, this report investigates potential deep sea hydrocarbon source rocks and chemical alterations of organic compounds during diagenesis. As far as thermal evolution is concerned, the black shales of the Falkland Plateau have attracted attention since Comer and Littlejohn (1977) attested that the organic matter is still in a low stage of maturity for oil generation but overmature for its present depth of burial. New methods are used in this study to reveal the stage of diagenesis and the thermal history of the black shales.

\section{METHODS}

\section{Sample Material}

At 18 different core locations in Hole 511, samples were taken from dark-colored intervals (presumably enriched in organic carbon) and were subjected to geochemical investigation. The samples were wrapped in aluminum foil on board and kept frozen until analysis started. Although the samples from Sections 511-3-4, 511-16-1, 511$62-5,511-64-4$, and 511-70-3 were thawed for an unknown length of 
time during transport, they seem not to have been affected judging by comparisons with those samples which were permanently frozen. Some of the 18 units analyzed were composite samples made up of materials from different sections within a core; thus, the notation 511-67-1/2/4 describes a unit composed of samples from Sections 1, 2 , and 4 of Core 511-67.

Table 1 contains information on sample identification, depth, stratigraphy, and lithology. For site location and lithologic units, see the site chapter, this volume.

\section{Experimental Procedures}

The frozen samples were freeze-dried and ground. The total carbon content was determined using a LECO carbon analyzer, and the organic carbon and total nitrogen were measured with a Perkin Elmer $240 \mathrm{~B}$ CHN analyzer. For the organic carbon and total nitrogen analysis, the weighed samples were progressively treated with hot $2 \mathrm{~N}, 4 \mathrm{~N}$, and $6 \mathrm{~N} \mathrm{HCl}$ in pure silver vessels to decompose any carbonate and dried at $80^{\circ} \mathrm{C}$ for $24 \mathrm{hr}$. prior to analysis.

A soxhlet apparatus $\left(20 \mathrm{hr}\right.$. at $\left.55^{\circ} \mathrm{C}\right)$ was used for the extraction of soluble compounds with dichloromethane. The extracts were separated into nonaromatic hydrocarbons, aromatic hydrocarbons, and heterocompounds on an $\mathrm{Al}_{2} \mathrm{O}_{3} / \mathrm{SiO}_{2}$ (1:2) column by elution with $n$-hexane, dichloromethane, and methanol, respectively. Where sample material was sufficient, some total extracts were also analyzed for $\mathrm{C}, \mathrm{H}, \mathrm{O}$, and $\mathrm{N}$ contents with the Perkin Elmer 240B analyzer.

The experimental conditions for Rock-Eval pyrolysis (Espitalié et al., 1977), gas chromatography, and gas chromatography/mass spectrometry and the procedure of kerogen concentration for microscopic investigations have been described in detail in previous reports (Rullkötter et al., 1981, and in press).

\section{RESULTS AND DISCUSSION}

\section{Amount and Type of Organic Matter}

The sediments of Late Jurassic to Recent age encountered in the basin province of the Falkland Plateau were divided into six lithologic units which vary considerably in their organic matter content. Very high amounts of organic carbon in the Late Jurassic to early Albian sediments of Unit 6 (Fig. 1 and Table 2) demonstrate the high potential of these sediments to accumulate organic matter under reducing environmental conditions. The relative uniformity of the sediments and the uniformity of the type of organic matter-close to a kerogen Type II (Fig. 2)-together with the constant, high organic carbon concentrations confirm that euxinic conditions were well established throughout Late Jurassic to early Albian times. The drop in organic carbon content near the Aptian/Albian boundary (Fig. 3, between 520 and $490 \mathrm{~m}$ ) indicates the development of a better-ventilated environmental system, which resulted in much lower organic carbon preservation in Albian and younger sediments (Fig. 1, Units 1-5). This development in the early Albian period is in agreement with the end of euxinic conditions in the southern of the two basins in the early South Atlantic Ocean (Reyment, 1980). The results from these two different environmental systems are discussed hereafter.

\section{Aptian-Upper Jurassic (Cores 58-70)}

According to Rock-Eval pyrolysis, the homogeneous black shales of Cores 59-70 are grouped between the kerogen Type II and Type III trend lines, but are close to Type II (Fig. 2). The relatively high hydrogen index values of these samples suggest a significant contribution of liptinitic organic matter. This is supported by microscopy and by the analysis of the extractable hydrocarbons. The maceral analysis of the typical black shales from Cores 70-59 reveals that liptinitic particles are an important or even dominant fraction of the kerogen particles (Table 3, Fig. 4). Structured and clearly identifiable liptinites represent only a small part of the total liptinites, most of which are present as detrital debris and amorphous organic matter that may originate from both autochthonous and allochthonous sources. In the clearly structured liptinites (Table 3), except for Section $511-57-2 / 3 / 5$, pollen, spores, and cuticles of terrestrial plants predominate. This does not necessarily indicate that terrestrial organic matter is a major contributor to the black shales, since a large portion of the primarily structured, autochthonous, marine organic matter may have followed a diagenetic pathway to form bituminous, unstructured organic matter. Thus, the bituminites and the abundant bituminous background matter occurring in all these sediments as a matrix for particular organic matter may originate from diagenetically degraded marine organisms, from microorganisms, and, to some extent, from amorphous organic matter in fecal aggregates.

Apart from these common features, microscopy also detects some differences within the otherwise homogeneous Aptian-Barremian shales. The inertinite and huminite particles (vitrinites of reflectance values below $0.5 \%$ are termed huminites) make up $7-8 \%$ in the deeper sections (511-70-3 and 511-69-2/3/4) and decrease to about $5 \%$ in Sections 511-67-1/2/4 through 511-62-5 (Table 3). As an exception, Section 511-65$1 / 2 / 3$ again shows a somewhat higher amount of inertinites and vitrinites. The very low concentrations in Sections 511-61-1/2/5 through 511-59-1 suggest that the supply of terrestrial organic matter generally decreased during Aptian-Barremian times. The high amounts of marine liptinitic matter in Section 511-57-2/3/5 (Table 3 ) are in agreement with the occurrence of nannofossil chalks at the top of the black shales. The relatively high amounts of inertinites and huminites in Sections 511$58-1 / 2 / 4 / C C$ and $511-57-2 / 3 / 5$ (Table 3 ) are no exception to the generally decreasing terrestrial contribution of organic debris during the Early and mid-Cretaceous. These two sections have low organic carbon contents, that are not comparable to the deeper sections (Table 1).

If we consider the Rock-Eval data (Fig. 2 and Table 1) and maceral compositions (Fig. 4) and compare them with the organic carbon contents (Table 1, Fig. 3), we may conclude that the high organic carbon contents in Lithologic Unit 6 are the result of excellent preservation of largely marine organic matter. A plot of organic carbon content versus the amount of huminite plus inertinite particles normalized to the quantity of liptinites demonstrates the positive correlation between total organic carbon enrichment and liptinite concentration (Fig. 5). The typical black shales form a cluster around points representing both high amounts of organic carbon and relatively high liptinite content. The upper shale intervals, Sections 511-61-1/2/5, 511-60-2/5/6, and 511-591 , differ slightly in that they have very high liptinite concentrations. 
Table 1. Geological and geochemical data for DSDP Hole 511 samples.

\begin{tabular}{|c|c|c|c|c|c|c|c|c|c|c|c|c|c|c|c|c|c|c|c|c|}
\hline \multirow{2}{*}{$\begin{array}{l}\text { Core/Section } \\
\text { (interval in cm) }\end{array}$} & \multirow{2}{*}{$\begin{array}{c}\text { Depth } \\
(\mathrm{m})\end{array}$} & \multirow{2}{*}{ Geological Age } & \multirow{2}{*}{$\begin{array}{l}\text { Lithology and } \\
\text { Lithologic Unit }\end{array}$} & \multirow{2}{*}{\multicolumn{3}{|c|}{ Rock (\% dry wt.) }} & \multirow{2}{*}{\multicolumn{2}{|c|}{ Extract }} & \multicolumn{3}{|c|}{ Chromatographic Fractions (wt.\%) } & \multicolumn{4}{|c|}{$\begin{array}{l}\text { Elemental Composition } \\
\text { of Bitumen }(\% / \text { wt.) }\end{array}$} & \multicolumn{5}{|c|}{ Rock-Eval Data } \\
\hline & & & & & & & & & \multicolumn{2}{|c|}{ Hydrocarbons } & $\begin{array}{c}\text { Hetero- } \\
\text { Compounds }\end{array}$ & c & H & o & $\mathrm{N}$ & $\begin{array}{c}\mathrm{H} \\
\text { Index }\end{array}$ & $\underset{\text { Index }}{o}$ & $\begin{array}{l}\mathrm{T}_{\max } \\
\left({ }^{\circ} \mathrm{C}\right)\end{array}$ & $\begin{array}{c}\mathrm{S}_{1} \\
\text { (mg/g rock) }\end{array}$ & $\begin{array}{c}\mathrm{S}_{1}+\mathrm{S}_{2} \\
\text { (mg/g rock) }\end{array}$ \\
\hline $3-4,135-150$ & 20 & early Oligocene & $\begin{array}{l}\text { Muddy diatomaceous ooze, } \\
\text { Subunit 2A }\end{array}$ & 1.02 & 0.082 & 0.25 & 102 & 10.0 & 17.2 & 18.8 & 64.0 & nd & nd & nd & nd & 34 & 178 & - & 0.06 & 0.41 \\
\hline $16-1,135-150$ & 139 & & & 0.60 & 0.048 & 0.01 & 161 & 26.7 & 6.8 & 3.4 & 89.8 & nd & nd & nd & nd & 394 & 92 & - & 0.16 & 2.28 \\
\hline $31-5,120-135$ & 261 & early Campanian & Zeolitic claystone, Unit 4 & 0.57 & 0.050 & 0.53 & 33 & 5.8 & nd & nd & nd & 80.1 & 10.1 & 8.3 & 0.14 & 27 & 375 & - & 0.04 & 0.18 \\
\hline $\begin{array}{l}55-1,100-106 \\
55-2,77-81 \\
55-4,0-5 \\
55-5,0-5 \\
55-6,49-54\end{array}$ & 485 & & $\begin{array}{l}\text { Muddy nannofossil chalk, } \\
\text { Unit } 5\end{array}$ & 0.07 & 0.027 & 3.35 & 5 & 7.4 & nd & nd & nd & 74.3 & 12.0 & 9.9 & trace & nd & nd & nd & nd & nd \\
\hline $56-5,123-128$ & 497 & early Albian & $\begin{array}{l}\text { Black shale in intervals with } \\
\text { white laminae, Unit } 6\end{array}$ & 0.68 & 0.033 & 0.00 & 105 & 15.5 & nd & nd & nd & 78.8 & 10.1 & 8.4 & 0.17 & 66 & 169 & - & 0.02 & 0.40 \\
\hline $\begin{array}{l}57-2,37-41,135-140 \\
57-3,125-129,135-139 \\
57-5,39-44,132-136\end{array}$ & 504 & & $\begin{array}{l}\text { Black shale in intervals with } \\
\text { gray and greenish zones, }\end{array}$ & 0.69 & 0.042 & 0.25 & 69 & 10.0 & 15.4 & 6.2 & 78.4 & nd & nd & nd & nd & 45 & 196 & 417 & 0.01 & 0.28 \\
\hline $\begin{array}{l}58-1,9-14,120-125 \\
58-2,9-14 \\
58-4,120-125 \\
\text { CC }\end{array}$ & 513 & Aptian & Unit 6 & 1.88 & 0.084 & 1.95 & 164 & 8.7 & 17.9 & 11.4 & 80.7 & 80.1 & 10.0 & 7.0 & 0.87 & 195 & 127 & 426 & $<0.01$ & 3.63 \\
\hline $59-1,45-48,143-147$ & 519 & & $\begin{array}{l}\text { Black shale with white } \\
\text { laminae of shell debris, } \\
\text { Unit } 6\end{array}$ & 8.18 & 0.360 & 0.58 & 1968 & 24.1 & 5.5 & 3.8 & 90.7 & nd & nd & nd & nd & 492 & 62 & 412 & 0.37 & 41.01 \\
\hline $\begin{array}{l}60-2,78-82 \\
60-5,84-89 \\
60-6,16-21\end{array}$ & 533 & $\begin{array}{c}\text { Barremian- } \\
\text { Aptian }\end{array}$ & $\begin{array}{l}\text { Muddy chalk, chalk, and black } \\
\text { shale (petroliferous), } \\
\text { Unit } 6\end{array}$ & 3.84 & 0.154 & 1.17 & 549 & 14.3 & 15.3 & 12.9 & 71.8 & 79.5 & 11.1 & 5.9 & 0.88 & 414 & 83 & 408 & 0.13 & 15.98 \\
\hline $\begin{array}{l}61-1,139-143 \\
61-2,0-7,110-115 \\
61-5,110-114\end{array}$ & 542 & & & 5.12 & 0.183 & 0.41 & 733 & 14.3 & 7.5 & 9.3 & 83.2 & 80.9 & 10.9 & 4.5 & 0.35 & 568 & 75 & 407 & 0.20 & 29.66 \\
\hline $62-5,135-150$ & 554 & & & 5.07 & 0.186 & 0.17 & 895 & 17.7 & 8.1 & 9.0 & 82.9 & nd & nd & nd & nd & 461 & 69 & 407 & 0.15 & 24.55 \\
\hline $64-4,135-150$ & 571 & & & 4.66 & 0.182 & 0.39 & 1052 & 22.6 & 8.1 & 9.9 & 82.0 & nd & nd & nd & nd & 481 & 81 & 413 & 0.11 & 21.89 \\
\hline $\begin{array}{l}65-1,41-46 \\
65-2,0-5 \\
65-3,52-57\end{array}$ & 577 & & Black shale (petroliferous), & 4.46 & 0.173 & 0.78 & 606 & 13.6 & 10.4 & 13.3 & 76.3 & 81.6 & 11.0 & 4.3 & 0.31 & 401 & 59 & 410 & 0.11 & 18.30 \\
\hline $\begin{array}{l}66-1,23-28 \\
66-3,145-150\end{array}$ & 586 & & $\begin{array}{l}\text { occasionally with white } \\
\text { laminae of shell debris, } \\
\text { Unit } 6\end{array}$ & 5.02 & 0.195 & 1.12 & 800 & 15.9 & 11.5 & 9.0 & 79.5 & nd & nd & nd & nd & 532 & 75 & 410 & 0.22 & 26.20 \\
\hline $\begin{array}{l}67-1,114-118 \\
67-2,1-4 \\
67-4,146-150\end{array}$ & 597 & Late Jurassic & & 5.43 & 0.201 & 0.68 & 565 & 10.4 & 22.5 & 12.5 & 65.0 & nd & nd & nd & nd & 527 & 55 & 414 & 0.25 & 28.30 \\
\hline $68-2,27-31,119-121^{a}$ & 606 & & & nd & nd & nd & nd & nd & nd & nd & nd & nd & nd & nd & nd & 381 & 73 & 407 & 2.80 & 17.24 \\
\hline $\begin{array}{l}69-2,145-150 \\
69-3,144-150 \\
69-4,0-5\end{array}$ & 617 & & & 4.11 & 0.181 & 0.00 & 453 & 11.0 & 22.8 & 10.3 & 66.9 & 81.4 & 11.2 & 4.2 & 0.27 & 345 & 58 & 424 & 0.12 & 14.47 \\
\hline $70-3,135-150$ & 627 & & & 4.31 & 0.175 & 0.32 & 842 & 19.6 & 11.0 & 9.6 & 79.4 & 81.4 & 11.8 & 3.9 & 0.22 & 446 & 45 & 428 & 0.16 & 19.25 \\
\hline
\end{tabular}




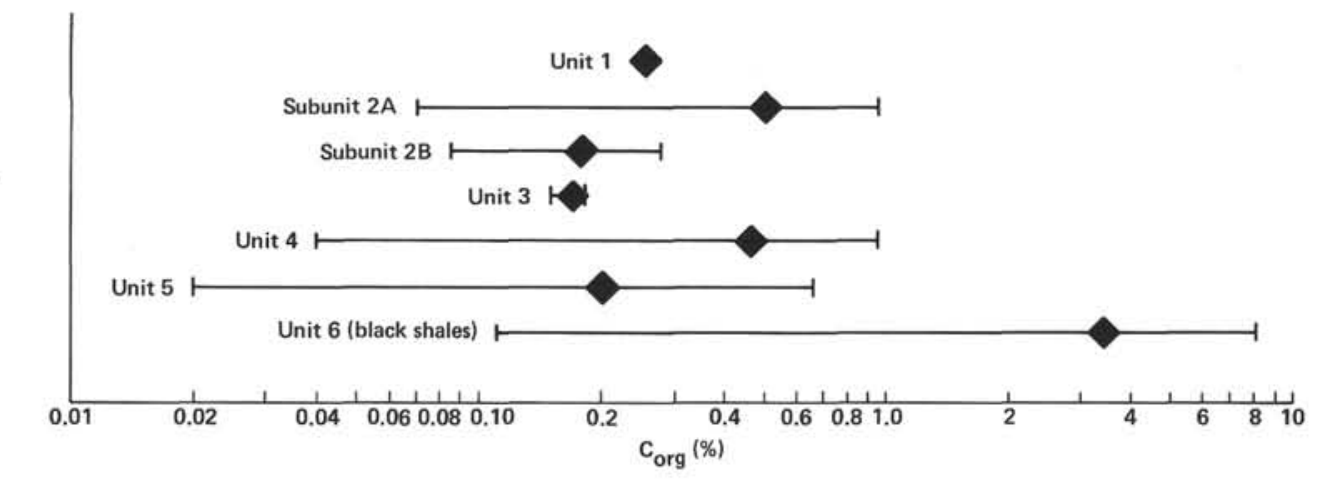

Figure 1. Organic carbon $\left(\mathrm{C}_{\text {org }}\right)$ mean values $(-)$ and total ranges $(\mapsto)$ for lithologic units or subunits of Site 511. The variation in the mean organic carbon values correlates well with the $\mathrm{Mn} / \mathrm{Fe}$ ratios as indicators of anoxic and oxic facies (Robert and Maillot, this volume). Ranges are calculated on the basis of 95 samples taken along the core profile (see Table 2).

Sections 511-58-1/2/4/CC (uppermost Aptian) and 511-57-2/3/5 (lower Albian) are grouped into a cluster characterized by higher contributions of huminites plus inertinites relative to liptinites, together with significantly lower organic carbon concentrations. This can be interpreted to mean a low supply of marine organic matter to the sediment and/or oxidation of organic matter before and during sedimentation. The result is a considerable decrease in total organic carbon and a relative enrichment of the more resistant terrestrial and inert organic matter. Within this sequence, however, Section $511-57-2 / 3 / 5$ contains an unusually high amount of predominantly marine liptinites relative to terrigenous spores and cuticules (Table 3 ). This apparent contradiction is resolved by the detection of a dominant population of particles with a very high reflectance in addition to the liptinites (Fig. 4); huminites and the related semifusinites are almost absent. Obviously, the organic matter which reached the sedimentary basin at that time consisted mainly of inert carbon and marine organisms rather than of herbaceous and woody material.

Comparison of the maceral analysis of Section 511$57 / 2 / 3 / 5$ with that of a stratigraphically higher section (Fig. 4) makes the "transitional zone" described by Deroo et al. (this volume) obvious. The relative amount of liptinite particles is comparable to that in the black shales downhole, whereas the distribution of the particles with higher reflectance is very similar to the sequence of the Albian-Maestrichtian claystones, which is low in organic carbon.

Compared with microscopy results (Fig. 4 and Table $3)$, the Rock-Eval pyrolysis results exhibit surprisingly low hydrogen and high oxygen indexes for Sections 511$57-2 / 3 / 5$ and $511-58-1 / 2 / 4 / C C$ (Fig. 2). This is especially pronounced for Section 511-57-2/3/5, which in the hydrogen index versus oxygen index diagram (Fig. 2) plots close to samples with minor liptinite content but high amounts of inert carbon (e.g., Sections 511-56-5, and 511-31-5 in Figs. 2 and 4). The high input of inert carbon lowers the hydrogen index and increases the oxygen index to some extent. The very high amount of liptinites present is, however, not consistent with the data of the Rock-Eval pyrolysis. An explanation for these contrasting results may be that oxidation of the lip- tinites has lowered their hydrogen potential values, as suggested by Deroo et al. (this volume) for some samples from Site 511. Based on this interpretation these two samples from Cores 57 and 58 in Figure 5 form a cluster characterized by the high amounts of inert carbon and oxidation of liptinites typical of a residual type of organic matter.

The analysis of the extractable nonaromatic hydrocarbons by the gas chromatography and combined gas chromatography/mass spectrometry reflects gradational differences within the black shale sequence similar to those just outlined. The capillary column chromatograms for the nonaromatic hydrocarbon fractions of some representative samples (Fig. 6) clearly show a more pronounced terrigenous influence near the base of the black shale unit (Section 511-70-3). This is indicated by the dominance of the long-chain wax alkanes $\left(C_{25}\right.$ to $\left.C_{35}\right)$ in the high-molecular-weight range. Section 511-62-5 contains considerably lower amounts of these $n$-alkanes relative to the complex mixture of steroid and triterpenoid hydrocarbons (Fig. 6). Finally, the peculiar feature detected by microscopy and Rock-Eval pyrolysis results for the composite Section 511-57-2/3/5 coincides with an unusual $n$-alkane distribution in this sample (Fig. 6). The maximum is found at $n-\mathrm{C}_{20}$, and there is a slow decrease in individual $n$-alkane concentrations toward $n-C_{31}$, with only a slight predominance of $n$-alkanes at odd carbon numbers. This $n$-alkane distribution may be the result of a mixture of rederived and bacterially degraded organic matter.

Polycyclic nonaromatic hydrocarbons are abundant in all of the black shale samples and are reduced to some extent only in the transitional samples near the Aptian/ Albian boundary. The complexity of the mixture, comprising saturated, mono- and diunsaturated isoprenoid, steroid, and triterpenoid hydrocarbons, is shown for Section 511-62-5 in Figure 7, which is part of the chromatogram in Figure 6, expanded to show greater detail. Compounds identified by gas chromatography/mass spectrometry on the basis of relative retention times and spectral interpretation are listed in Table 4 for seven black shale samples. Steroid hydrocarbons are dominant in all of the samples; this is interpreted to be consistent with the microscopic detection of major amounts 
Table 2. Organic carbon and total nitrogen contents of DSDP Site 511 samples.

\begin{tabular}{|c|c|c|}
\hline $\begin{array}{c}\text { Core/Section } \\
\text { (interval in cm) }\end{array}$ & $\begin{array}{c}\text { Organic } \\
\text { Carbon } \\
\text { (\% dry wt.) }\end{array}$ & $\begin{array}{c}\text { Total } \\
\text { Nitrogen } \\
\text { (\% dry wt.) }\end{array}$ \\
\hline $1-4,31-33$ & 0.26 & 0.036 \\
\hline $2, \mathrm{CC}(7-9)$ & 0.17 & 0.036 \\
\hline $2-3,120-122$ & 0.26 & 0.031 \\
\hline $2-4,10-12$ & 0.07 & 0.032 \\
\hline $3-4,41-43$ & 0.75 & 0.066 \\
\hline $3-5,7-8$ & 0.96 & 0.068 \\
\hline $4-2,61-62$ & 0.91 & 0.067 \\
\hline $4-2,118-120$ & 0.79 & 0.073 \\
\hline $5-4,90-92$ & 0.60 & 0.066 \\
\hline $5-5,7-9$ & 0.70 & 0.057 \\
\hline $6-3,90-92$ & 0.56 & 0.060 \\
\hline $6-4,58-60$ & 0.71 & 0.060 \\
\hline $11-3,110-111$ & 0.76 & 0.071 \\
\hline $12-1,80-82$ & 0.76 & 0.072 \\
\hline $15-1,72-74$ & 0.46 & 0.051 \\
\hline $16-1,90-92$ & 0.69 & 0.061 \\
\hline $17-2,60-62$ & 0.34 & 0.037 \\
\hline $18-1,70-72$ & 0.40 & 0.041 \\
\hline $20-2 ; 64-66$ & 0.39 & 0.044 \\
\hline $20-2,110-112$ & 0.44 & 0.035 \\
\hline $21-1,15-17$ & 0.09 & 0.026 \\
\hline $21-1,46-48$ & 0.28 & 0.025 \\
\hline $24-1,43-46$ & 0.18 & 0.026 \\
\hline $24-3,98-99$ & 0.15 & 0.026 \\
\hline $25-1,103-104$ & 0.04 & 0.028 \\
\hline $27-1,42-43$ & 0.23 & 0.031 \\
\hline $28-1,78-80$ & 0.08 & 0.028 \\
\hline $28-4,112-113$ & 0.27 & 0.032 \\
\hline $28-7,0-1$ & 0.56 & 0.052 \\
\hline 29, CC & 0.30 & 0.031 \\
\hline $30-1,14-15$ & 0.71 & 0.047 \\
\hline $31-1,136-139$ & 0.78 & 0.047 \\
\hline $31-4,133-135$ & 0.46 & 0.310 \\
\hline $32-2,140-144$ & 0.30 & 0.023 \\
\hline $33-2,92-94$ & 0.63 & 0.050 \\
\hline $33-5,106-109$ & 0.63 & 0.051 \\
\hline $34-1,1-3$ & 0.95 & 0.057 \\
\hline $34-2,113-115$ & 0.70 & 0.055 \\
\hline $34-7,51-54$ & 0.43 & 0.038 \\
\hline $36-2,63-66$ & 0.41 & 0.033 \\
\hline $36-2,141-143$ & 0.59 & 0.047 \\
\hline $37-1,50-51$ & 0.93 & 0.055 \\
\hline $38-2,41-42$ & 0.66 & 0.051 \\
\hline $38-3,64-65$ & 0.74 & 0.051 \\
\hline $39-3,84-85$ & 0.36 & 0.030 \\
\hline $40-3,31-32$ & 0.49 & 0.040 \\
\hline $41-1,123-125$ & 0.67 & 0.051 \\
\hline $41-2,115-116$ & 0.10 & 0.022 \\
\hline $41-3,36-37$ & 0.13 & 0.034 \\
\hline $42-4,97-99$ & 0.51 & 0.039 \\
\hline $43-1,23-25$ & 0.23 & 0.035 \\
\hline $44-3,51-53$ & 0.30 & 0.034 \\
\hline $44-3,52-53$ & 0.46 & 0.034 \\
\hline $45-2,91-93$ & 0.49 & 0.036 \\
\hline $45-2,93-95$ & 0.31 & 0.036 \\
\hline $47-2,84-86$ & 0.35 & 0.038 \\
\hline $47-6,72-74$ & 0.17 & 0.030 \\
\hline $48-2,97-99$ & 0.07 & 0.022 \\
\hline $48-4,48-50$ & 0.13 & 0.038 \\
\hline $49-5,38-40$ & 0.11 & 0.031 \\
\hline $50-1,107-109$ & 0.09 & 0.031 \\
\hline $50-3,62-64$ & 0.02 & 0.026 \\
\hline $51-1,141-143$ & 0.03 & 0.056 \\
\hline $52-2,22-23$ & 0.08 & 0.029 \\
\hline $53-5,65-66$ & 0.06 & 0.024 \\
\hline $54-5,62-63$ & 0.16 & 0.032 \\
\hline $55-1,49-51$ & 0.18 & 0.028 \\
\hline $55-5,40-42$ & 0.07 & 0.032 \\
\hline $55-5,42-43$ & 0.21 & 0.031 \\
\hline $56-5,56-58$ & 0.56 & 0.035 \\
\hline $56-5,58-60$ & 0.66 & 0.031 \\
\hline $57-2,14-16$ & 0.29 & 0.015 \\
\hline $57-3,100-102$ & 2.02 & 0.090 \\
\hline $57-5,82-84$ & 0.64 & 0.033 \\
\hline $58-1,71-72$ & 0.83 & 0.043 \\
\hline $58-1,72-74$ & 0.63 & 0.041 \\
\hline $58-4,72-74$ & 0.30 & 0.023 \\
\hline $59-1,86-89$ & 2.92 & 0.126 \\
\hline $59-1,88-89$ & 2.80 & 0.123 \\
\hline $59-3,105-107$ & 2.06 & 0.086 \\
\hline $60-1,32-34$ & 4.64 & 0.184 \\
\hline $61-2,46-48$ & 5.39 & 0.179 \\
\hline $61-2,81-82$ & 4.19 & 0.146 \\
\hline $62-1,22-24$ & 4.75 & 0.161 \\
\hline $62-3,54-56$ & 2.83 & 0.122 \\
\hline $63-1,107-109$ & 3.25 & 0.134 \\
\hline $63-3,16-17$ & 3.94 & 0.153 \\
\hline $64-3,128-130$ & 2.64 & 0.122 \\
\hline $65-3,8-10$ & 0.12 & 0.013 \\
\hline $66-3,92-94$ & 5.28 & 0.197 \\
\hline $67-3,43-45$ & 4.86 & 0.174 \\
\hline $68-2,71-72$ & 3.89 & 0.171 \\
\hline $69-3,75-77$ & 3.72 & 0.163 \\
\hline $69-5,2-4$ & 1.40 & 0.085 \\
\hline $70-4,96-98$ & 3.90 & 0.159 \\
\hline
\end{tabular}

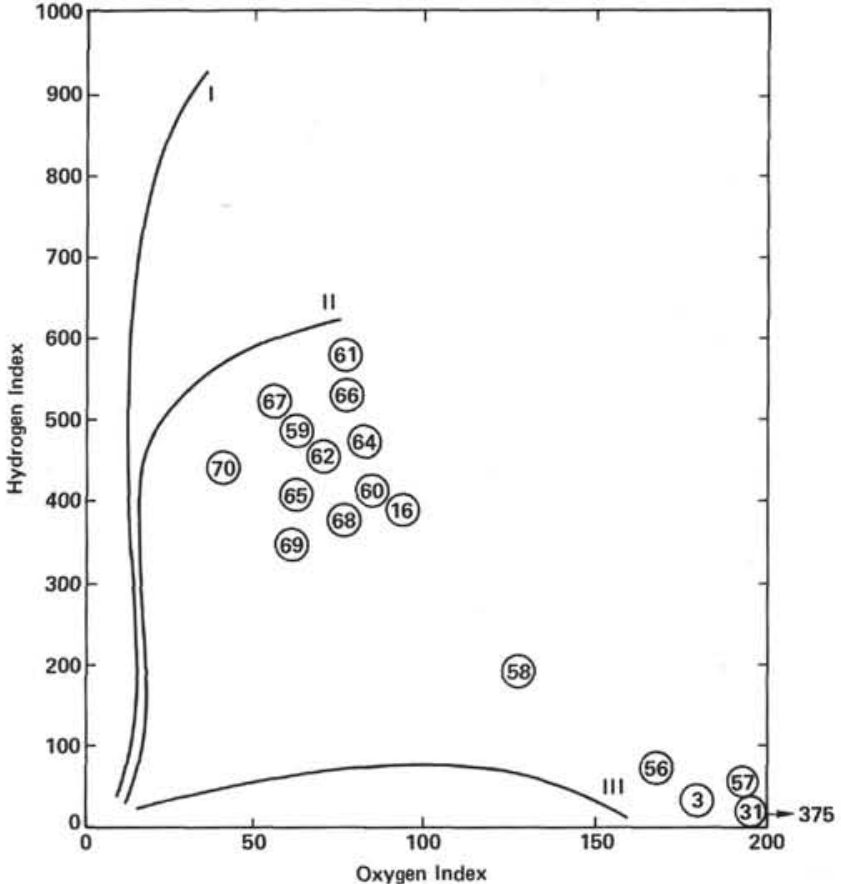

Figure 2. Results of Rock-Eval pyrolysis expressed in a hydrogen index versus oxygen index diagram. Core numbers in circles; for full sample intervals, see Table 1 . Core 55 sample not analyzed because of its low organic carbon content. I, II, III = kerogen types I-III.)

of marine liptinitic organic matter. Many of the steroid hydrocarbons have undergone skeletal rearrangement, probably induced by clay mineral catalysis (Rubinstein et al., 1975).

The distribution of rearranged and regular sterenes and steradienes is shown in Figure 8 by their major mass-spectrometric fragment ions $\mathrm{m} / \mathrm{z} 257$ and $\mathrm{m} / \mathrm{z}$ 255 , respectively. Also shown are the corresponding higher homologs, probably 4-methyl sterenes and steradienes $(\mathrm{m} / \mathrm{z} 271$ and $\mathrm{m} / \mathrm{z} 269)$. Together with various hopanoid hydrocarbons (Ourisson et al., 1979), the 4methyl steroids may indicate a major contribution of microbial mass to the organic matter in the black shales. The saturated sterane content in Section 511-62-5 is shown in Figure 8 by the m/z 217 mass chromatogram. The concentration of these compounds, compared to their unsaturated analogs, is relatively low in the shallower part of the black shales unit but increases slightly downhole (Table 4).

\section{Tertiary-Albian (Cores 3-57)}

Both the quantity of organic carbon (Table 1) and the type of organic matter described in detail for Section $511-57-2 / 3 / 5$ reflect a transition toward a type of organic matter in the Albian to Tertiary sediments that contrasts with those of the black shales. Low organic carbon values (Fig. 1), associated with a low hydrogen index but a high oxygen index (Fig. 2) and generally very low amounts of liptinites (Fig. 4), testify to the residual character of this type of organic matter.

Lithologic Subunit 2B and Units 3 and 5, consisting of pelagic clays, calcareous and zeolitic oozes, and red- 


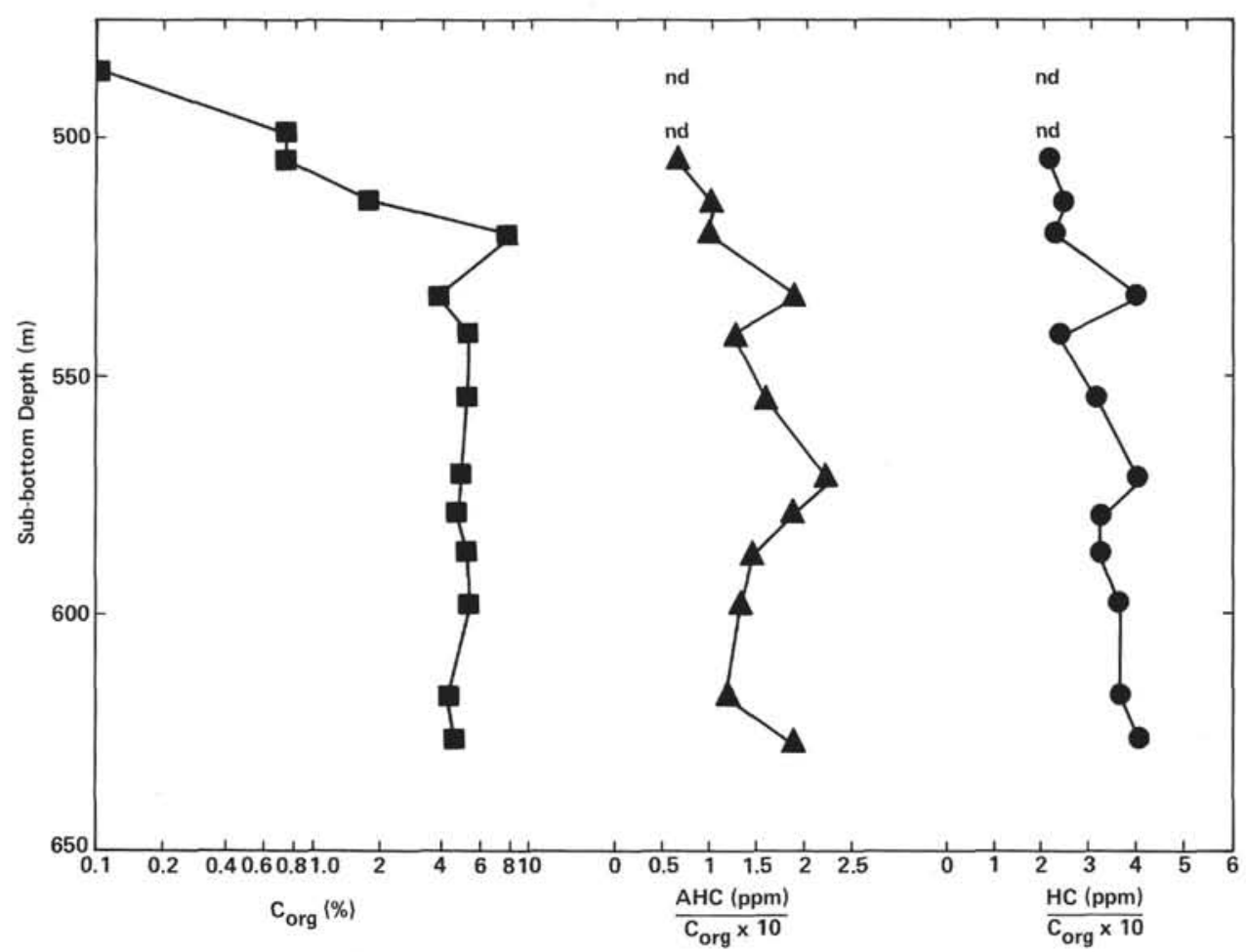

Figure 3. Variations and trends of organic carbon $\left(\mathrm{C}_{\mathrm{org}}\right)$, and of aromatic hydrocarbons $(\mathrm{AHC})$ and total hydrocarbons (HC) normalized to organic carbon, as a function of depth at DSDP Site 511 (nd = not determined).

Table 3. Maceral analysis of particles $\geq 3 \mu \mathrm{m}$ and general description of kerogen background matter in samples from DSDP Hole 511.

\begin{tabular}{|c|c|c|c|c|c|}
\hline Core-Section ${ }^{a}$ & $\begin{array}{l}\text { Inertinites } \\
+\underset{(\text { vol. } \%)}{\text { Huminites }}\end{array}$ & $\begin{array}{c}\text { Total } \\
\text { Liptinites } \\
\text { (vol, } \% \text { ) }\end{array}$ & $\begin{array}{l}\text { Pollen, } \\
\text { Spores, } \\
\text { Cuticules } \\
\text { (vol.\%) }\end{array}$ & $\begin{array}{l}\text { Algal } \\
\text { Bodies } \\
\text { (vol.\%) }\end{array}$ & $\begin{array}{l}\text { Visual Description } \\
\text { of Kerogen } \\
\text { Background Matter }\end{array}$ \\
\hline 3-4 & 52 & 2.8 & nd & nd & Inertinitic debris \\
\hline $16-1$ & 23.2 & 25.8 & 1.8 & 2.5 & Humic-partly bituminous \\
\hline $31-5$ & 10.1 & 4.9 & 1.5 & $0.7 ?$ & Inertinitic debris \\
\hline $55-1 / 2 / 4 / 5 / 6$ & nd & nd & nd & nd & nd \\
\hline $56-5$ & 71 & 8.2 & 1.3 & 0.9 & Inertinitic debris \\
\hline $57-2 / 3 / 5$ & 14.5 & 52 & 4.5 & 6.0 & High amounts of liptinitic detritus \\
\hline $58-1 / 2 / 4 / \mathrm{CC}$ & 4 & 16 & nd & nd & Partly humic-bituminous \\
\hline 59-1, & 1.8 & 9.3 & 0.6 & 0.6 & Bituminous \\
\hline $60-2 / 5 / 6$ & 2.2 & 16.7 & 0.9 & 0.5 & Bituminous \\
\hline $61-1 / 2 / 5$ & 2.5 & 21.1 & 1.9 & 1.6 & Bituminous \\
\hline $62-5$ & 5.4 & 13.7 & 0.7 & 0.2 & Bituminous-partly humic \\
\hline $64-4$ & 5.4 & 18.6 & 2.1 & 0.7 & Bituminous-partly humic \\
\hline $65-1 / 2 / 3$ & 7.7 & 6.9 & 0.5 & 0.1 & Mixed bituminous-humic \\
\hline $66-1 / 3$ & 3.6 & 14.3 & 0.4 ? & $0.1 ?$ & Bituminous-partly humic \\
\hline $67-1 / 2 / 4$ & 5.3 & 12.5 & 0.9 & 0.3 & Bituminous-partly humic \\
\hline $68-2$ & \multicolumn{2}{|c|}{ Contaminated-nd } & & & \\
\hline $69-2 / 3 / 4$ & 8.1 & 12.5 & 1.4 & 0.3 & Mixed bituminous-humic \\
\hline $70-3$ & 7.2 & 16.2 & 1.8 & 0.6 & Bituminous-partly humic \\
\hline
\end{tabular}

dish brown claystones, exhibit low mean organic carbon values, about $0.2 \%$; the dark gray oozes of Subunit $2 \mathrm{~A}$ and the greenish gray zeolitic clays and claystones of Unit 4 show somewhat higher mean organic carbon concentrations, about $0.5 \%$ (Fig. 1). These latter units represent the late Eocene-early Oligocene and ConiacianSantonian intervals, respectively; both are characterized by a rather high sedimentation rate that probably led to a slightly better preservation of organic matter by rapid burial under oxic bottom-water conditions. Judging by the residual character of the organic matter, the Albian to Tertiary sediments from Site $\mathbf{5 1 1}$ form a third cluster if the Core 16 sample is excluded (Fig. 5). Particles with a high reflectance range $(0.9 \%$ to about $1.5 \%)$ form the dominant fraction in the Albian to middle Maestrichtian sediments (Sections 511-57-2/3/5, 511-56-5, and 511-31-5 in Fig. 4).

The occurrence of bimacerites (single, sedimentary, organic particles composed of two maceral types) with reflectance values of $1.0-1.4 \%$ and $\geq 2.0 \%$, respectively, in Sections 511-16-1, 511-31-5, and 511-67-1/2/4, suggests that the particles within the reflectance range $0.9-1.6 \%$ may, at least partly, originate from recycled and oxidized organic matter. The presence and abun- 
dance of particles in that reflectance range in all sections (Fig. 4) leads to the assumption that oxidized, probably eroded organic matter has been transported to the Site 511 area throughout the whole time span covered by the sediments analyzed. Thus, particles with a higher reflectance range $(1.6 \%)$ can be defined as inertinites. Huminite particles are in a range of about $0.3-0.5 \%$ in Hole 511. Semifusinites exhibit a reflectance $0.2-0.4 \%$ higher than the corresponding huminites. Thus, the particles in Figure 4 that are in a reflectance range of about $0.5-0.8 \%$ are determined to be semifusinites, a determination sustained by their abundance, which correlates well with the abundance of the huminites.

Section 511-16-1 of the Tertiary Subunit $2 \mathrm{~A}$ is the only section outside the black shales that exhibits a hydrogen index similar to the shales (Fig. 2). The low organic carbon content and the large amounts of inertinite and huminite particles (probably oxygenated, Fig. 4) shift this sample close to the cluster in Figure 5 that is typical of the "transitional zone" (e.g., Cores 57 and 58). Disseminated liptinitic material (not discernible under the microscope) is probably dominant and is responsible for the high hydrogen index, despite the relative abundance of huminite and inertinite particles detected by microscopy (Fig. 4). Section 511-16-1 is also the only Tertiary sample containing significant amounts of polycyclic nonaromatic hydrocarbons. The cyclic hydrocarbons are the products of primary deposition and an early stage of diagenesis-for instance, $17 \beta(\mathrm{H})$-hopanes (Fig. 6 , Table 4). The dominant compounds in the capillary chromatogram of the nonaromatic hydrocarbon fraction are, however, long-chain wax alkanes of terrigenous origin (Fig. 6).

Although only a few random samples of the AlbianTertiary sequence were analyzed, it can be concluded from the sediment facies and the low organic carbon contents (Fig. 1) that the organic facies of the Albian and Upper Cretaceous-Tertiary sequence is represented mainly by a residual type of organic matter, with a few exceptions such as Subunit 2A, Section 511-16-1.

The pronounced difference between the two contrasting types of organic matter is also discernible from the elementary analysis of the bitumens (soluble organic matter). Inert organic carbon yields very few or no compounds extractable by organic solvents. Thus, the bitumen originates mainly from organic matter that is liptinitic and, to some extent, humic. Because of the marked differences in elementary composition between aquatic and terrestrial organic matter, black shales with a predominantly marine organic input are clearly separated from the overlying sequence when plotted in a $\mathrm{C} / \mathrm{N}-$ $\mathrm{O} / \mathrm{C}$ diagram (Fig. 9). The liptinites of the sedimentary sequence overlying the black shales contain important or even major portions of land plant lipids and are probably affected by oxidation. As is to be expected for terrestrial and/or oxygenated organic matter with high oxygen and low nitrogen contents (Waples, 1977), bitumens in Sections 511-56-5, 511-55-1/2/4/5/6, and 51131-5 exhibit much high $\mathrm{C} / \mathrm{N}$ and $\mathrm{O} / \mathrm{C}$ ratios than the black shales. The variation within the black shale samples is, later in this chapter, tentatively explained as an effect of diagenetic evolution. Characterization of the type of organic matter by the atomic $\mathrm{C} / \mathrm{N}-\mathrm{O} / \mathrm{C}$ ratios of the bitumen generally confirms the results based on Rock-Eval pyrolysis (Fig. 2) and microscopy (Table 3, Figs. 4 and 5); it differs principally in that it does not include any contribution of inert carbon, as Rock-Eval and microscopy do. This fact has to be taken into consideration when, for example, Rock-Eval data from Section 511-58-1/2/4/CC are compared with $\mathrm{C} / \mathrm{N}-\mathrm{O} / \mathrm{C}$ ratios of bitumen. The low $\mathrm{C} / \mathrm{N}$ ratio suggests a predominantly marine lipid source; the somewhat higher $\mathrm{O} / \mathrm{C}$ ratio may reflect oxidation as described earlier and suggested by Deroo et al. (this volume).

\section{Thermal Maturation of the Black Shales}

The stage of thermal evolution of the organic matter can be determined by both geochemical and microscopical data.

The reflectance of disseminated vitrinites in a rock is widely accepted as an indicator of the thermal history of organic matter and commonly applied for rank determinations (e.g., Bartenstein and Teichmüller, 1974; Bostick and Alpern, 1977). At DSDP Site 511, vitrinite reflectance ranges between $0.32 \% \overline{\mathrm{R}}_{0}$ at the top of the black shales and about $0.45 \% \overline{\mathrm{R}}_{0}$ at the bottom-hole depth of 632 meters (Fig. 10). Oil generation is believed to start at a level of $0.5-0.6 \% \overline{\mathrm{R}}_{0}$ (Hunt, 1979); thus these shales are still in a low stage of maturity.

The reflectance values given for Sections 511-57-2/ $3 / 5,511-59-1$, and $511-60-2 / 5 / 6$ in Figure 10 are not completely certain because of the low amounts of wellcharacterized humic particles (Fig. 4). In a few casesfor instance, Sections 511-62-5, 511-67-1/2/4, and 51170-3-bimodal distributions of huminites/vitrinites may lead to an equivocal determination of maturity, so that either the first or the second peak is accepted as valid for a rank determination. Humic material originates from many different plant constituents that generate a large variety of such particles in coals and rocks during diagenetic alteration (Jacob, 1980). Thus bimodal distributions may be caused by differences in the precursor compounds of the humic material. The bimodal distributions have been ignored in this case, since the mean values over the entire range best fit the over- and underlying sections. Since maturation is progressive with increases in temperature and depth, it would be unreasonable to assume, for instance, a lower or significantly higher huminite/vitrinite reflectance in Section 511-67$1 / 2 / 4$, compared with the unimodal distribution in the overlying Section 511-66-1/3 (Fig. 4).

Rank determination by measurement of vitrinite reflectance is supported by other geochemical parameters which all point to a low level of maturity. The kerogens of the black shales still have high hydrogen and oxygen index values, indicative of a diagenetic stage (Fig. 2). The amounts of total extractable organic compounds (normalized to organic carbon) and the relative proportions of hydrocarbons are still low (Table 1). The moderate amounts of generated light hydrocarbons agree with this interpretation (Schaefer et al., this volume). 

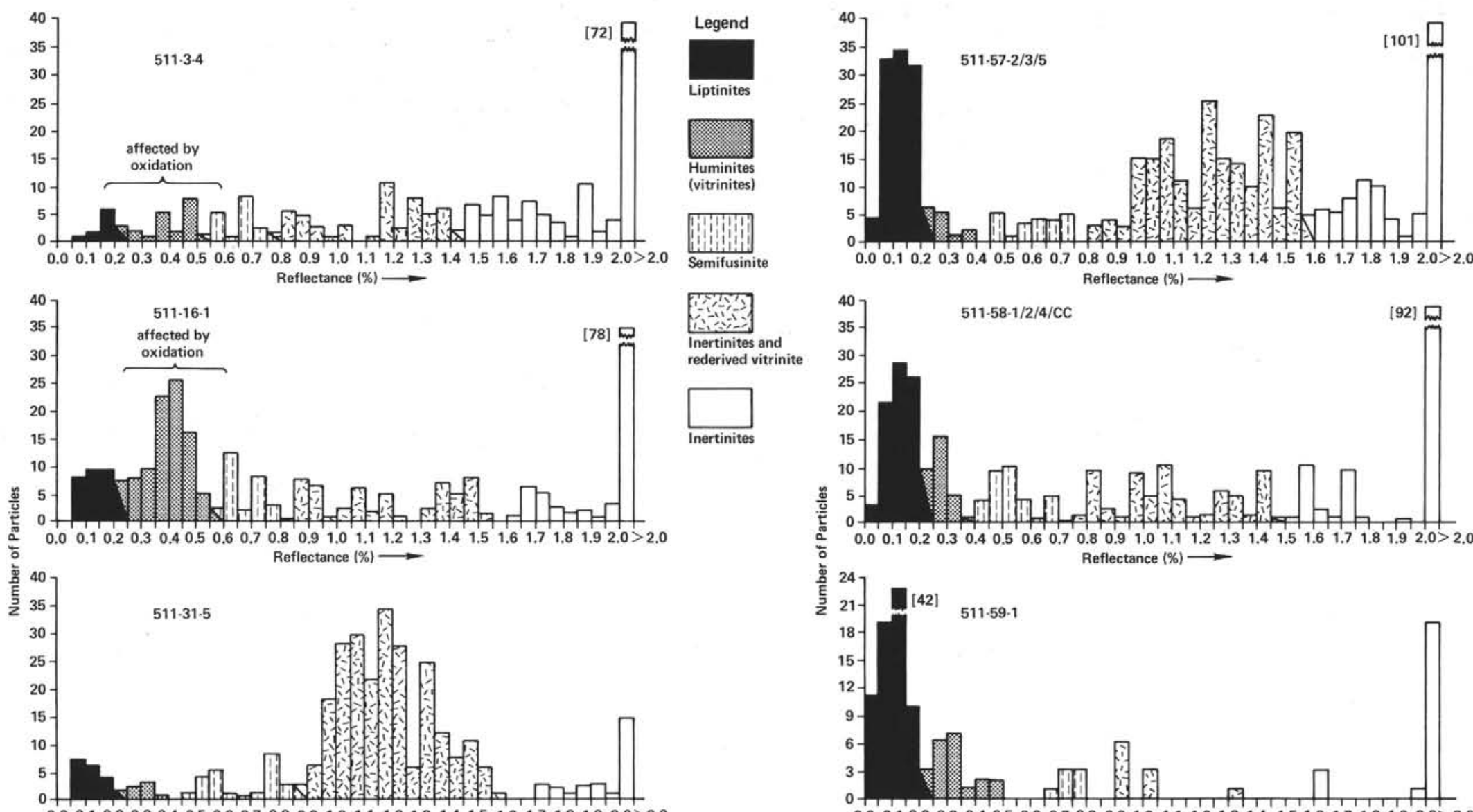

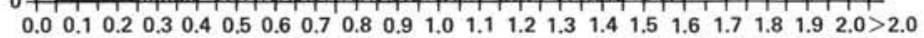

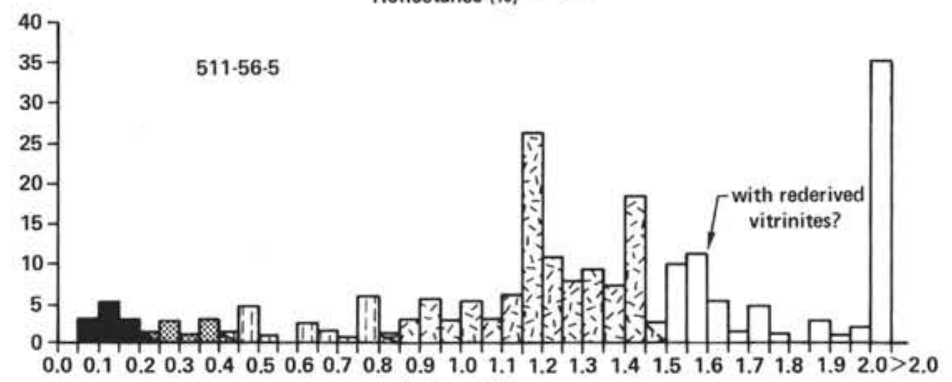

Reflectance $(\%) \longrightarrow$
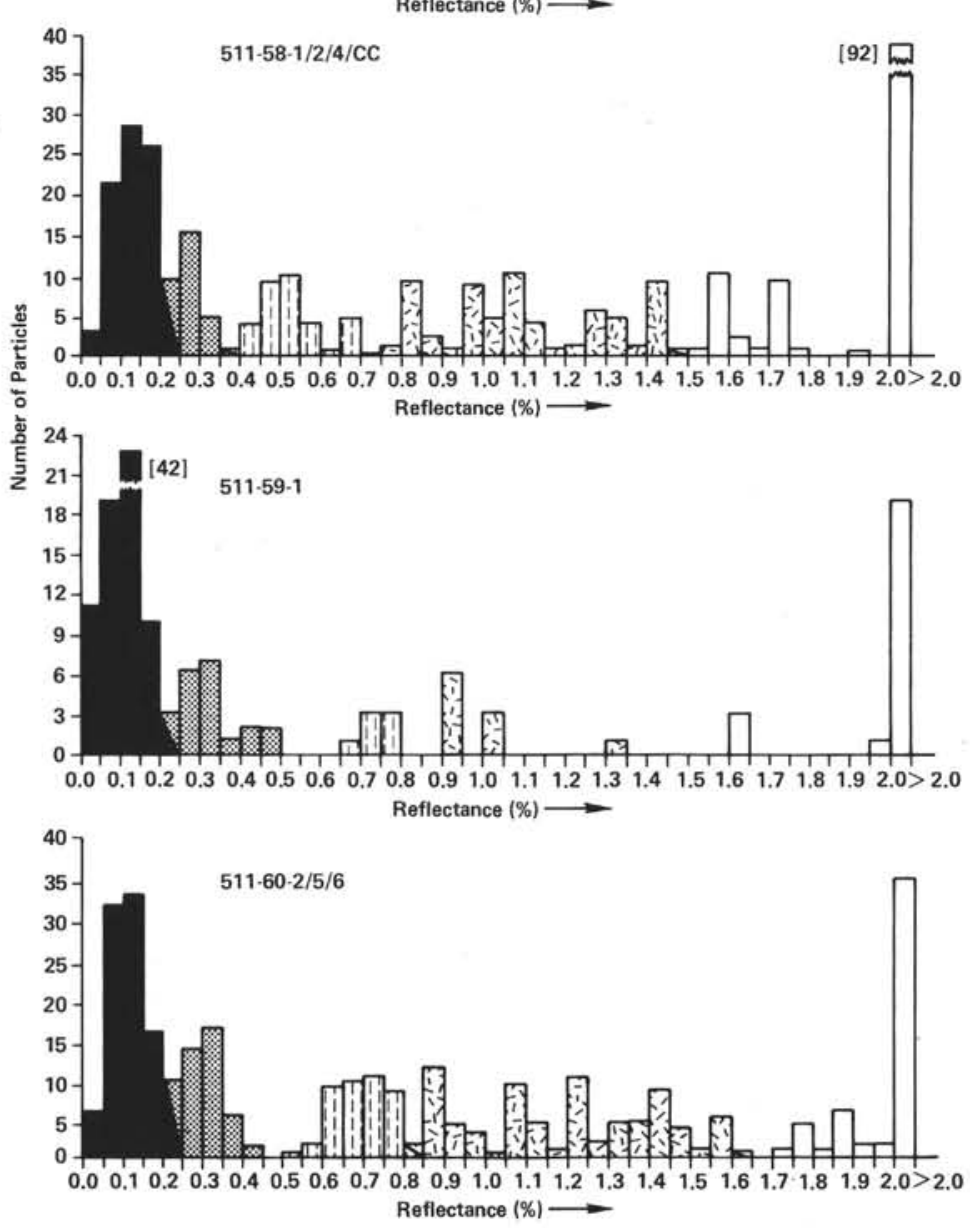

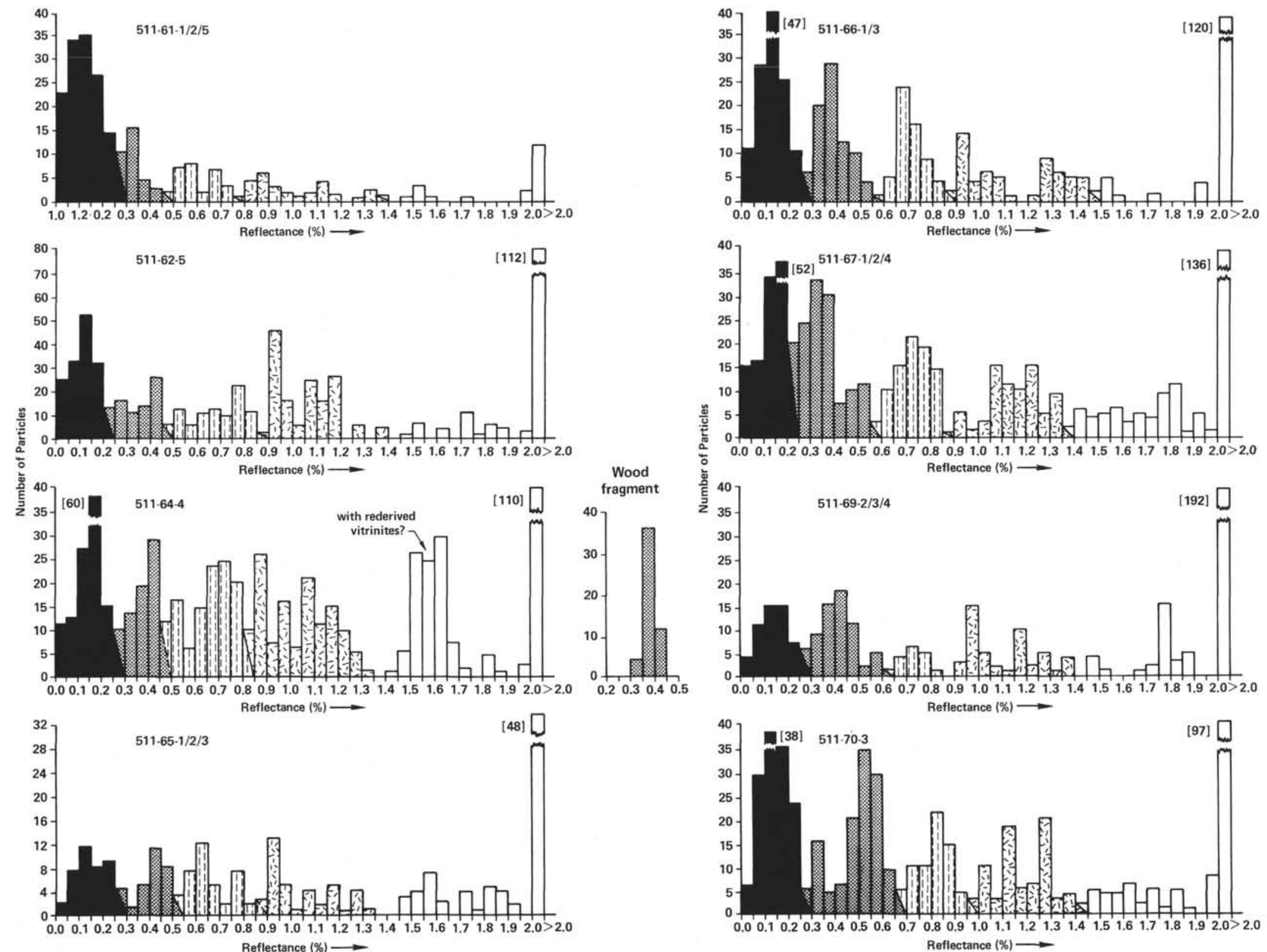

Figure 4. Reflectance histograms of liptinites, huminites (vitrinites), and inertinites larger than $10 \mu \mathrm{m}$ in kerogen concentrates of sediments from DSDP Site 511. Liptinites are not representative in all cases because of their translucency and internal reflections. The occurrence of bimacerites in some sections and the distribution pattern of particles in the reflectance range $0.85-1.6 \% \overline{\mathrm{R}}_{0}$ allows a further classification of the inertinites into semifusinites and mixed rederived vitrinites and inertinites. Core 55 sample not analyzed because of its low organic carbon content; Core 68 sample contaminated. 


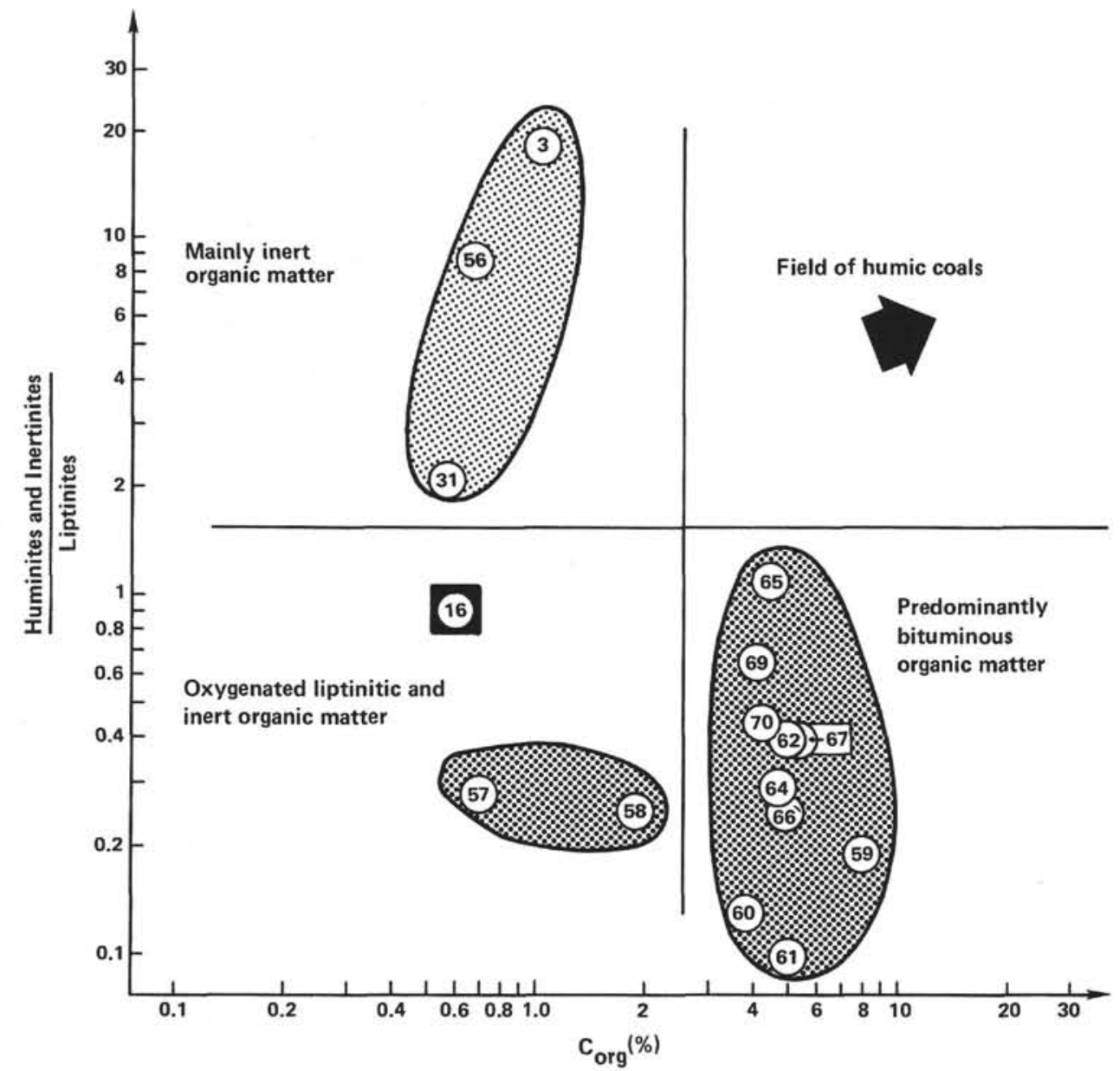

Figure 5. Kerogen classification based on ratios of (huminites + inertinites)/liptinites as revealed by microscopy versus organic carbon content. Cores 57 and 58 of the "transitional zone," characterized by both high amounts of inert carbon and/or oxygenated liptinitic material, have an intermediate position between the black shales and samples dominated by an inert type of organic matter. Section 511-16-1, exhibiting a rather high hydrogen index but low organic carbon content (Table 1), forms an exception. Although the kerogen background matter is not considered here, the pattern correlates well with the data obtained by Rock-Eval pyrolysis (Fig. 2). (Core number in circles; for full sample identification, see Table 1.)

The investigation of the extractable $\mathrm{C}_{15}+$ nonaromatic hydrocarbons provides further support both for the low stage of maturity of the organic matter in the black shales and also for a slight increase in maturity downhole within the black shale sequence. The most obvious indication of the low maturity is the great abundance of unsaturated steroid and triterpenoid hydrocarbons in all black shale samples. Regular sterenes (IIIVII; see Appendix for compound structures) decrease in concentration relative to regular steranes (VIII) as depth of burial increases (Table 4). A similar trend for the rearranged sterenes (I,II) could not be detected. Neohop13(18)-enes (IX) and hop-17(21)-enes (X) are abundant in all samples and there is no definite change in relative concentrations with depth, except for the decreasing amounts of trisnorneohop-13(18)-ene relative to trisnorhop-17(21)-ene. 17 $\beta(\mathrm{H})$-hopanes (XII) predominate over the thermally more stable $17 \alpha(\mathrm{H})$-hopanes (XI) (Van Dorsselaer et al., 1977) in all samples, and $17 \beta(\mathrm{H})$ homohopane is the most abundant single compound within the homologous series. Finally, the predominance of the odd-numbered, long-chain $n$-alkanes over their even-numbered homologs in the deepest sample analyzed (Section 511-70-3; Fig. 6) also shows that the black shales have not yet reached the zone of thermal hydrocarbon generation.

Considering the short depth interval of about 140 meters, the increase of the vitrinite reflectance from $0.32 \% \overline{\mathrm{R}}_{0}$ at the top of the shales to about $0.45 \% \overline{\mathrm{R}}_{0}$ at 630 meters sediment depth appears to be rather high and would suggest an extremely rapid increase of maturation with increasing depth of burial (Fig. 10). The difficulties in establishing a valid trend certainly arise in part from the short interval over which the black shale samples were investigated. Furthermore, it is well known that, at the same level of maturity, vitrinite reflectance appears to be lower in the presence of abundant bituminous organic matter (Hutton and Cook, 1980). The values obtained from the upper, highly bituminous part of the shales are perhaps too low. Shifting these data to 


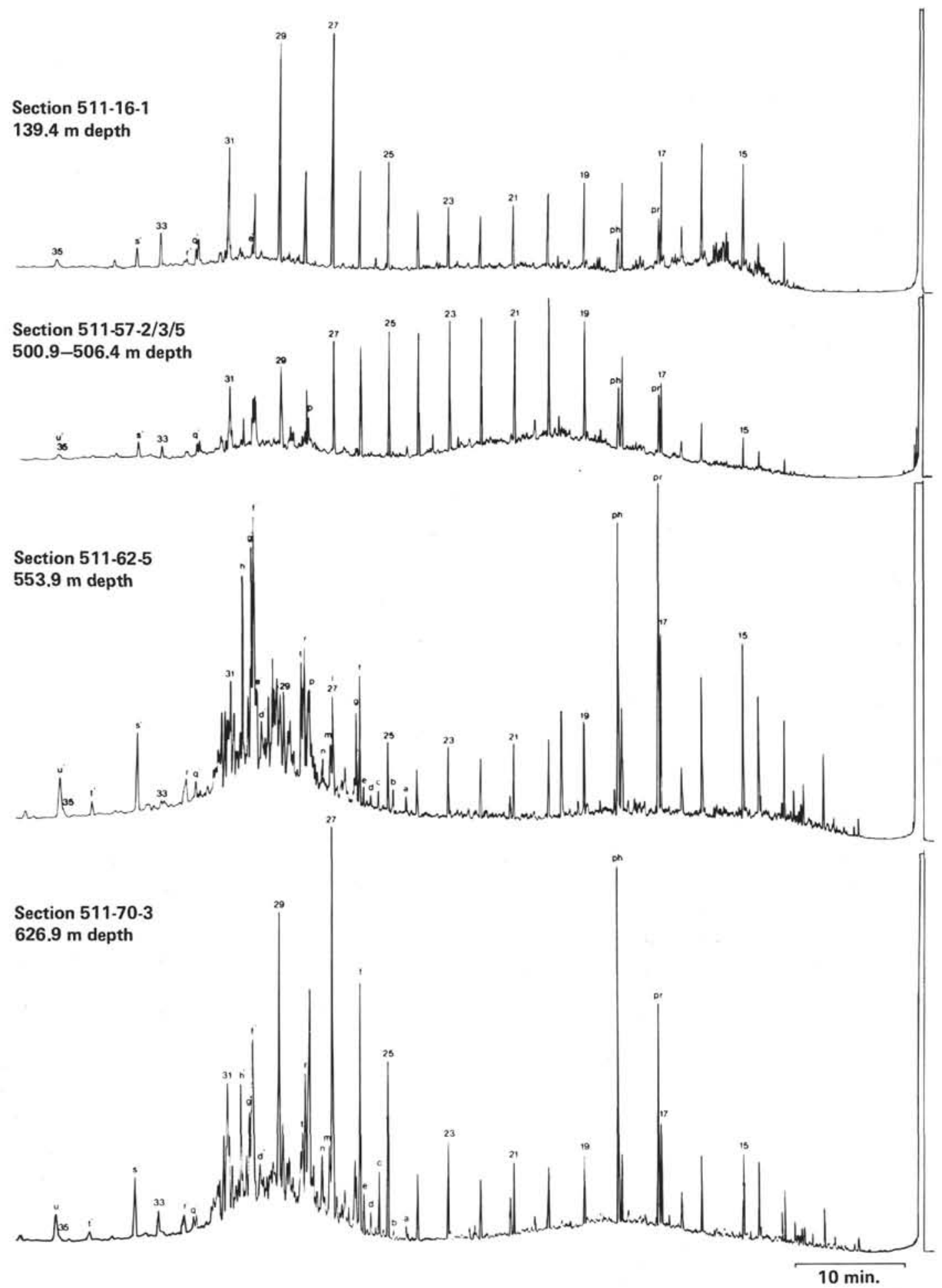

Figure 6. Capillary column gas chromatograms of the nonaromatic hydrocarbon fractions of four sediment samples from DSDP Site 511. Numbers indicate $n$-alkanes; lettered compounds were identified by GC/MS and are listed in Table 4. Conditions: Varian 3700 gas chromatograph with FID detector; $20 \mathrm{~m} \times 0.3 \mathrm{~mm}$ ID, SE 54; carrier gas, helium; temperature program, $80-265^{\circ} \mathrm{C}$ at $3^{\circ} \mathrm{C} / \mathrm{min}$.)

higher values would result in a lower maturation gradient than shown in Figure 10. The reflectance value obtained from the wood fragment seems, however, to be most reliable, since the huminites are in a stage of transition from a texto-ulminite to an eu-ulminite. This tran- sition takes place in a reflectance interval between $0.4 \%$ and $0.6 \% \overline{\mathrm{R}}_{0}$ (Hagemann, pers. comm.).

An increasing maturation with depth of burial is also discernible from the atomic $\mathrm{C} / \mathrm{N}$ and $\mathrm{O} / \mathrm{C}$ ratios of the bitumen (soluble organic matter), which decrease slowly 


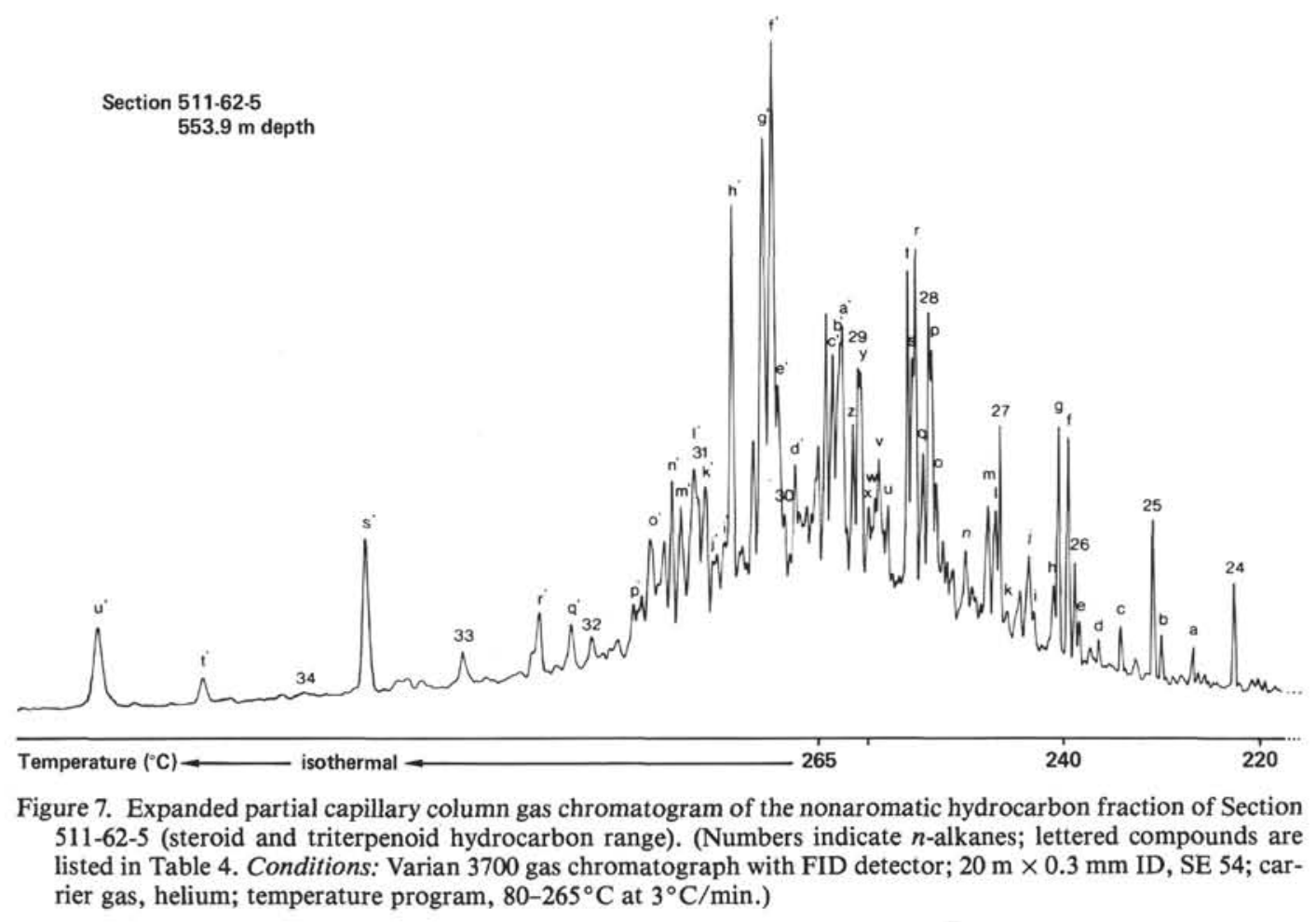

for $\mathrm{O} / \mathrm{C}$ and increase rapidly for $\mathrm{C} / \mathrm{N}$ with increasing depth (Fig. 9). The rapid increase of the $\mathrm{C} / \mathrm{N}$ ratios with depth is affected not only by diagenesis but also by the increasing contribution of land-derived organic matter downhole, which shifts the values to higher $\mathrm{C} / \mathrm{N}$ and $\mathrm{O} / \mathrm{C}$ ratios. Despite the increasing terrestrial input, the $\mathrm{O} / \mathrm{C}$ ratios are, however, slowly decreasing with depth. Thus, the increasing $\mathrm{C} / \mathrm{N}$ and decreasing $\mathrm{O} / \mathrm{C}$ ratios of the bitumen as depth of burial increases are interpreted as a loss of functional groups from heterocompounds during the early stages of thermal evolution. The slight increase, with depth, in the amounts of hydrocarbons (normalized to organic carbon, Fig. 3) supports this increasing maturation and is consistent with the interpretation that some organic compounds have lost functional groups.

In most cases it was not possible to determine the maturation in the Upper Cretaceous and Tertiary claystones because of the residual nature of the organic matter. Apparently, the majority of the huminite particles are affected by oxidation. Thus, the reflectance value of $0.26 \% \mathrm{R}_{0}$ from a few particles in the Tertiary Section 511-16-1 seems plausible but is not substantiated.

Apart from the increase in the maturation of organic matter, the absolute level of maturity appears to be rather high, considering the actual shallow depth of burial. This fact has already been observed by Comer and Littlejohn (1977) for the black shales at DSDP Sites 327 and 330. The deepest sample at Site 511, Section 511-70-3, has already reached a fairly high level of maturation, corresponding to $0.45 \% \overline{\mathrm{R}}_{0}$. Interpreted as a mixture of thermogenic and biogenic origin (Burke et al., 1981), the low $C_{1} / C_{2}$ ratios calculated from the composition of core liner gases (site report, this volume) together with the "paraffinic" character of light hydrocarbons (Schaefer et al., this volume) support the idea of a relatively high level of maturity at shallow depth.

The relatively high maturation level may reflect two main circumstances: (1) the shales may actually have been more deeply buried in the Mesozoic, but there occurred an uplift and a part of the Upper Cretaceous/ Paleocene sedimentary sequence was eroded; and/or (2) a higher temperature gradient may have acted on the sediments in the past. Although the vitrinite reflectance of $0.26 \% \bar{R}_{0}$ in the Tertiary claystones at a depth of 139 meters has been determined only tentatively and the vitrinite data of the upper part of the Cretaceous black shales appear to be too low, there is no indication of a major break in the vitrinite reflectance trend at the Cretaceous/Tertiary unconformity.

A significantly higher overburden in the past therefore seems unlikely. Paleontological considerations (discussions of the shipboard party) and the data of the porosity trend (Bayer, pers. comm.) also suggest that there was no additional overburden above the unconformity exceeding 400 meters. Comer and Littlejohn (1977) considered the time interval of the unconformity to be too short for significantly deeper burial and subsequent erosion.

Thus the question arises whether the present geothermal heat flow at Site 511 may account for the maturity, or whether there have been changes in heat flow during the geological past. The problem may be solved by comparing the temperature regime and the maturation level of organic matter on the Falkland Plateau with those of other sedimentary basins with a known geological and thermal history. Compared with samples from the Landau 2 borehole (Rhine Valley, 
Table 4. Branched and cyclic compounds identified in the nonaromatic hydrocarbon fractions of DSDP Hole 511 samples.

\begin{tabular}{|c|c|c|c|c|c|c|c|c|c|c|}
\hline & \multirow[b]{2}{*}{ Compound } & \multirow{2}{*}{$\begin{array}{l}\text { General } \\
\text { Structure }\end{array}$} & \multicolumn{8}{|c|}{ Core-Section } \\
\hline & & & $\overline{16-1}$ & $57-2 / 3 / 5$ & $59-1$ & $62-5$ & $64-4$ & $66-1 / 3$ & $69-2 / 3 / 4$ & $70-3$ \\
\hline pr & pristane & & ++ & ++ & +++ & +++ & +++ & +++ & $++t$ & +++ \\
\hline $\mathrm{ph}$ & phytane & & ++ & ++ & +++ & +++ & +++ & +++ & +++ & +++ \\
\hline a & $\begin{array}{l}\text { tetracyclic alkane } \\
\qquad(\mathrm{M}+328, \mathrm{BP} 313,243,231,217)\end{array}$ & & & & + & + & + & + & + & + \\
\hline b & $\begin{array}{l}\mathrm{C}_{27} \text {-sterene } \\
(\mathrm{M}+370,355,327,314,257,239)\end{array}$ & & & & + & + & + & + & + & + \\
\hline c & $\mathrm{C}_{27}$-rearranged sterene & 1, $R=H$ & & $\mathrm{tr}$ & + & + & + & + & + & + \\
\hline d & $\begin{array}{l}\text { sterene? } \\
\qquad(\mathrm{M}+370, \mathrm{BP} 206,355,219,121)\end{array}$ & & & & tr & + & + & + & + & + \\
\hline e & $\mathrm{C}_{27}$-rearranged sterene? & & & & + & + & + & + & + & + \\
\hline f & $\mathrm{C}_{27}$-rearranged sterene & $1, R=H$ & & + & ++ & ++ & ++ & ++ & ++ & ++ \\
\hline 8 & $\begin{array}{l}\mathrm{C}_{27} 7_{\text {-sterene }} \\
\left(\mathrm{M}^{+}=\mathrm{BP} 370,355,279,257,215\right)\end{array}$ & & & tr & ++ & ++ & ++ & ++ & + & + \\
\hline h & $\begin{array}{l}\mathrm{C}_{28 \text {-sterene }} \\
(\mathrm{M}+384, \mathrm{BP} 121,369,257,206)\end{array}$ & & & & ++ & + & + & + & + & + \\
\hline i & $\mathrm{C}_{28}$-steradiene (rearranged?) & & & $\mathrm{tr}$ & ++ & + & $\mathrm{tr}$ & tr & tr & \\
\hline j & $\begin{array}{l}\mathrm{C}_{29} \text {-sterene } \\
\quad+\text { other sterenes/steradienes } \\
(\mathrm{M}+384, \mathrm{M}+382, \mathrm{M}+370)\end{array}$ & & & tr & + & $\stackrel{+}{t r}$ & \pm & + & + & $\underset{t r}{+}$ \\
\hline k & $\mathrm{C}_{29}$-sterene $(\mathrm{M}+398,257,220)$ & & & $\operatorname{tr}$ & tr & tr & tr & $\operatorname{tr}$ & tr & + \\
\hline$i$ & $\mathrm{C}_{28}$-rearranged sterene & $\mathrm{I}, \mathrm{R}=\mathrm{CH}_{3}$ & & + & ++ & + & ++ & + & + & ++ \\
\hline $\mathrm{m}$ & $\begin{array}{l}\mathrm{C}_{28 \text {-sterene }} \\
(\mathrm{M}+384,369,314,257,215)\end{array}$ & & & & ++ & + & + & + & + & + \\
\hline $\mathrm{n}$ & $\mathrm{C}_{29}$-steradiene (rearranged?) & & & & + & + & tr & + & tr & tr \\
\hline o & $\begin{array}{l}5 \beta \text {-cholestane } \\
\text { + } 4 \text {-methylsteradiene }\end{array}$ & VIII, $\mathrm{R}=\mathrm{H}$ & & tr & + & + & $\begin{array}{l}+ \\
\text { tr }\end{array}$ & + & + & + \\
\hline p & $\begin{array}{l}\mathrm{C}_{29} \text {-rearranged sterene } \\
22,29,30 \text {-trisnorneohop-13(18)-ene }\end{array}$ & $\begin{array}{l}\mathrm{I}, \mathrm{R}=\mathrm{C}_{2} \mathrm{H}_{5} \\
\text { IX, } \mathrm{R}=\mathrm{H}\end{array}$ & & + & $\begin{array}{c}-1 \\
++ \\
+\end{array}$ & + & $\begin{array}{l}-1 \\
++ \\
+\end{array}$ & tr & $+\underset{\text { tr }}{++}$ & ++ \\
\hline$q$ & $\begin{array}{l}\text { 4-methyl- } \mathrm{C}_{27} \text {-rearranged sterene } \\
(\mathrm{M}+384,271)\end{array}$ & II & & tr & + & + & + & + & + & + \\
\hline $\mathrm{r}$ & cholest-4-ene & IV, $\mathrm{R}=\mathrm{H}$ & & + & +++ & +++ & ++ & ++ & + & + \\
\hline s & $\begin{array}{l}\text { 4-methyl- } \mathrm{C}_{27} \text {-sterene } \\
\text { + cholest-2-ene }\end{array}$ & III & & & + & + & + & + & + & + \\
\hline $\mathrm{t}$ & cholest-5-ene & $\mathrm{V}, \mathrm{R}=\mathrm{H}$ & & + & +++ & ++ & ++ & + & + & + \\
\hline & $+5 \alpha$-cholestane & Viil, $\mathrm{R}=\mathrm{H}$ & $\mathrm{tr}$ & + & + & ++ & ++ & ++ & + & + \\
\hline $\mathrm{u}$ & 22,29,30-trisnorhop-17(21)-ene & $X, R=H$ & & tr & + & + & + & + & + & + \\
\hline $\mathrm{v}$ & 24-methylcholesta-4,22-diene & vi & & + & +++ & tr & tr & & & \\
\hline & + 4-methyl-C 27 -sterene & & & tr & + & + & + & + & + & + \\
\hline w & 24-methylcholesta-5,22-diene & VII & & + & +++ & tr & tr & & & \\
\hline $\mathrm{x}$ & $22,29,30$-trisnor-17 $\alpha(\mathrm{H})$-hopane & $\mathrm{XI}, \mathrm{R}=\mathrm{H}$ & + & + & + & + & + & + & + & + \\
\hline $\mathrm{y}$ & 24-methyl-5B-cholestane & VIII, $\mathrm{R}=\mathrm{CH}_{3}$ & & tr & + & + & + & + & + & + \\
\hline & + 4-methyl- $C_{27}$-sterene & & & & + & + & + & + & tr & tr \\
\hline$z$ & 4-methyl-C $C_{27}$-sterene & & & & ++ & + & + & + & + & + \\
\hline$a^{\prime}$ & $22,29,30$-trisnor-17 $\beta(\mathrm{H})$-hopane & $\mathrm{XII}, \mathrm{R}=\mathrm{H}$ & tr & + & + & + & + & + & + & + \\
\hline$b^{\prime}$ & 24-methylcholest-4-ene & IV, $\mathrm{R}=\mathrm{CH}_{3}$ & & + & ++ & + & + & + & tr & + \\
\hline $\mathrm{c}^{\prime}$ & 24-methylcholest-5-ene & $\mathrm{V}, \mathrm{R}=\mathrm{CH}_{3}$ & & + & ++ & + & + & + & tr & + \\
\hline & +24 -methyl-5 $\alpha$-cholestane & viII, $\mathrm{R}=\mathrm{CH}_{3}$ & tr & + & ++ & + & + & + & + & + \\
\hline$d^{\prime}$ & 24-ethyl-5 $\beta$-cholestane & VIII, $\mathrm{R}=\mathrm{C}_{2} \mathrm{H}_{5}$ & & tr & + & + & + & + & + & + \\
\hline $\mathrm{e}^{\prime}$ & 30-nor-17 $\alpha(\mathrm{H})$-hopane & $\mathrm{XI}, \mathrm{R}=\mathrm{C}_{2} \mathrm{H}_{5}$ & + & + & + & + & + & + & + & + \\
\hline$f^{\prime}$ & 24-ethylcholest-4-ene & IV, $\mathrm{R}=\mathrm{C}_{2} \mathrm{H}_{5}$ & & ++ & +++ & +++ & +++ & ++ & + & \\
\hline & +30-norneohop-13(18)-ene & $\mathrm{IX}, \mathrm{R}=\mathrm{C}_{2} \mathrm{H}_{5}$ & & + & + & + & + & ++ & ++ & ++ \\
\hline & +30-norhop-17(21)-ene & $\mathrm{X}, \mathrm{R}=\mathrm{C}_{2} \mathrm{H}_{5}$ & & + & + & + & + & ++ & ++ & ++ \\
\hline$g^{\prime}$ & 24-ethylcholest-5-ene & $\mathrm{v}, \mathrm{R}=\mathrm{C}_{2} \mathrm{H}_{5}$ & & ++ & ++ & ++ & ++ & ++ & + & \\
\hline & +24 -ethyl-5 $\alpha$-cholestane & viII, $\mathrm{R}=\mathrm{C}_{2} \mathrm{H}_{5}$ & tr & + & ++ & ++ & ++ & ++ & + & + \\
\hline $\mathrm{h}^{\prime}$ & hop-17(21)-ene & $\mathrm{X}, \mathrm{R}=\mathrm{CH}\left(\mathrm{CH}_{3}\right)_{2}$ & & ++ & ++ & +++ & +++ & +++ & ++ & ++ \\
\hline $\mathrm{j}^{\prime}$ & 30-normoretane & XIII & + & + & + & + & + & tr & tr & tr \\
\hline $\mathrm{j}^{\prime}$ & 4-methyl- $\mathrm{C}_{29}$-sterene & & & & + & + & + & to & tr & tr \\
\hline $\mathrm{k}^{\prime}$ & 4-methyl-C 29 -sterene & & & & + & + & + & + & + & + \\
\hline 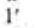 & $17 \alpha(\mathrm{H})$-hopane & $\mathrm{XI}, \mathrm{R}=\mathrm{CH}\left(\mathrm{CH}_{3}\right)_{2}$ & + & + & ++ & + & ++ & + & + & + \\
\hline $\mathrm{m}^{\prime}$ & fern-8-ene & XIV & + & + & + & + & + & + & + & + \\
\hline $\mathrm{n}^{\prime}$ & neohop-13(18)-ene & IX, $\mathrm{R}=\mathrm{CH}\left(\mathrm{CH}_{3}\right)_{2}$ & & + & + & + & ++ & + & ++ & + \\
\hline $0^{\prime}$ & 30-nor-17ß $(\mathrm{H})$-hopane & $\mathrm{XII}, \mathrm{R}=\mathrm{C}_{2} \mathrm{H}_{5}$ & + & + & + & + & + & + & + & + \\
\hline & + fern-9(11)-ene & $\mathrm{XV}$ & + & + & + & + & + & + & + & + \\
\hline$p^{\prime}$ & homohop-17(21)-ene & $\mathrm{X}, \mathrm{R}=\mathrm{CH}\left(\mathrm{CH}_{3}\right) \mathrm{C}_{2} \mathrm{H}_{5}$ & & tr & + & + & + & + & + & + \\
\hline$q^{\prime}$ & $17 \alpha(\mathrm{H})$-homohopane & $\mathrm{XI}, \mathrm{R}=\mathrm{CH}\left(\mathrm{CH}_{3}\right) \mathrm{C}_{2} \mathrm{H}_{5}$ & + & + & + & + & + & + & + & + \\
\hline $\mathrm{r}^{\prime}$ & $17 \beta(\mathrm{H})$-hopane & XII, $\mathrm{R}=\mathrm{CH}\left(\mathrm{CH}_{3}\right)_{2}$ & + & + & + & + & + & + & + & + \\
\hline $\mathbf{s}^{\prime}$ & $17 \beta(\mathrm{H})$-homohopane & $\mathrm{XII}, \mathrm{R}=\mathrm{CH}\left(\mathrm{CH}_{3}\right) \mathrm{C}_{2} \mathrm{H}_{5}$ & ++ & ++ & +++ & ++ & +++ & +++ & +++ & +++ \\
\hline $\mathrm{t}^{\prime}$ & $17 \beta(\mathrm{H})$-bishomohopane & XII, $\mathrm{R}=\mathrm{CH}\left(\mathrm{CH}_{3}\right) \mathrm{C}_{3} \mathrm{H}_{7}$ & tr & tr & + & + & + & + & + & + \\
\hline $\mathrm{u}^{\prime}$ & lycopane & XVI & & & ++ & ++ & ++ & ++ & + & + \\
\hline
\end{tabular}

Note: Compounds are marked in the gas chromatograms shown in Figures 6 and 7 (letter symbols), and are listed in order of elution from the capillary column. Estimated abundances: $+++=$ major,$++=$ intermediate, $+=$ minor, $\mathrm{tr}=$ trace amounts. $\mathrm{M}^{+}=$molecular ion; $\mathrm{BP}=$ basic peak of mass spectrum $(100 \%)$

a See Appendix to this chapter for compound structures.

West Germany) and the Northwest African continental margin, the organic matter at DSDP Site 511 reaches an equivalent level of maturity at a very shallow depth (Table 5). On the Northwest African continental margin, the comparable level at much greater depths is undoubtedly associated with the much lower temperature gradient, $42^{\circ} \mathrm{C} / \mathrm{km}$. If one does not assume an additional overburden on the Falkland Plateau in the past, the comparison clearly shows that at DSDP Site 511 there must have been a higher paleotemperature gradient, which can be estimated using the time-temperature relationship of the organic matter maturation.
The rapid increase of maturation with depth shown in Figure 10 (this seems to be too high, for reasons discussed earlier) and the generation trend of light hydrocarbons (Schaefer et al., this volume) would lead us to expect the onset of oil generation at an extrapolated depth of about $800-900$ meters, in sediments which would have an estimated age of at least 130 m.y. At this depth, a reaction temperature of about $80^{\circ} \mathrm{C}$ is necessary for such a level of maturity (Connan, 1974; Wright, 1980). Thus, assuming no additional overburden, a paleothermal gradient of about $100^{\circ} \mathrm{C} / \mathrm{km}$ can be calculated. This, of course, would be a very unlikely situa- 


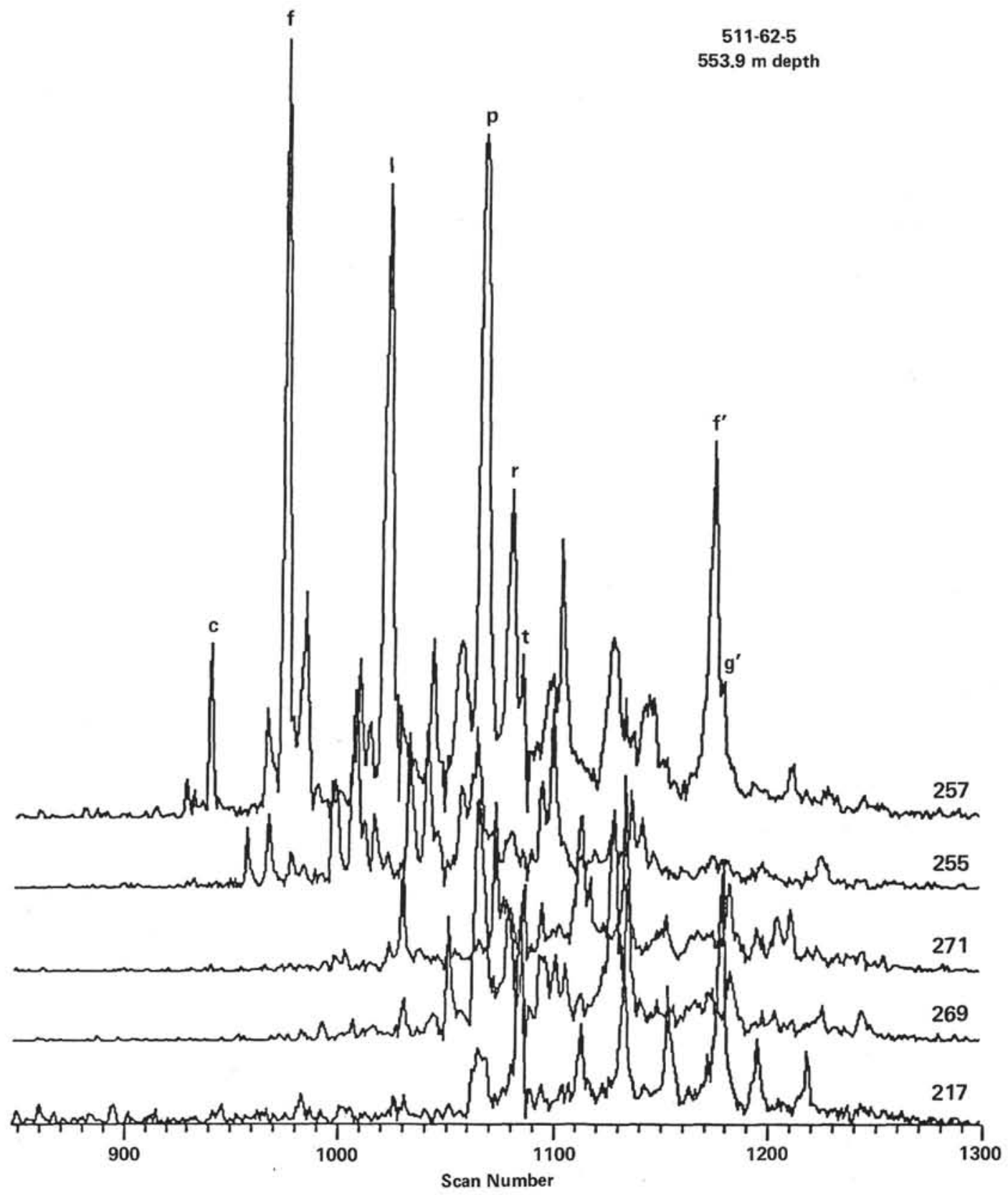

Figure 8. Mass chromatograms of 5 key fragment ions indicating the sterene/steradiene ( $\mathrm{m} / \mathrm{z} 257 / 255)$, 4-methyl sterene/steradiene $(\mathrm{m} / \mathrm{z} 271 / 269)$, and sterane $(\mathrm{m} / \mathrm{z} 217)$ distributions in the nonaromatic hydrocarbon fraction of Section 511-62-5. (Conditions: Varian MAT $112 \mathrm{~S}$ mass spectrometer, $70 \mathrm{eV}$, source temperature, $220^{\circ} \mathrm{C}, 2.3$ s/scan, coupled directly to a Varian 3700 gas chromatograph; GC conditions as in Fig. 6.)

tion, not normally seen in nature except in regions of volcanic activity.

Allowing for an additional overburden of approximately 400 meters above the unconformity, the bottomhole sediments of DSDP Hole 511 reach a level of maturity comparable to that of Landau 2 at a depth of between 800 and 900 meters and 1100 meters (Table 5). In this case, the present temperature gradient of $70^{\circ} \mathrm{C} / \mathrm{km}$, if it has lasted for the past 120 m.y., would be sufficient to account for the observed maturity. This is in agreement with the geological considerations advanced by the
DSDP Leg 71 shipboard party, which excluded an additional overburden of more than $\mathbf{4 0 0}$ meters and a lower paleotemperature gradient.

\section{PALEOENVIRONMENTAL COMPARISON WITH THE BLACK SHALES OF THE CAPE BASIN; CONCLUSIONS}

Sediments of the black shale facies of Cretaceous age have been encountered in many South and North Atlantic DSDP holes (Tissot et al., 1979, 1980). Without doubt, they reflect periods of reducing conditions dur- 


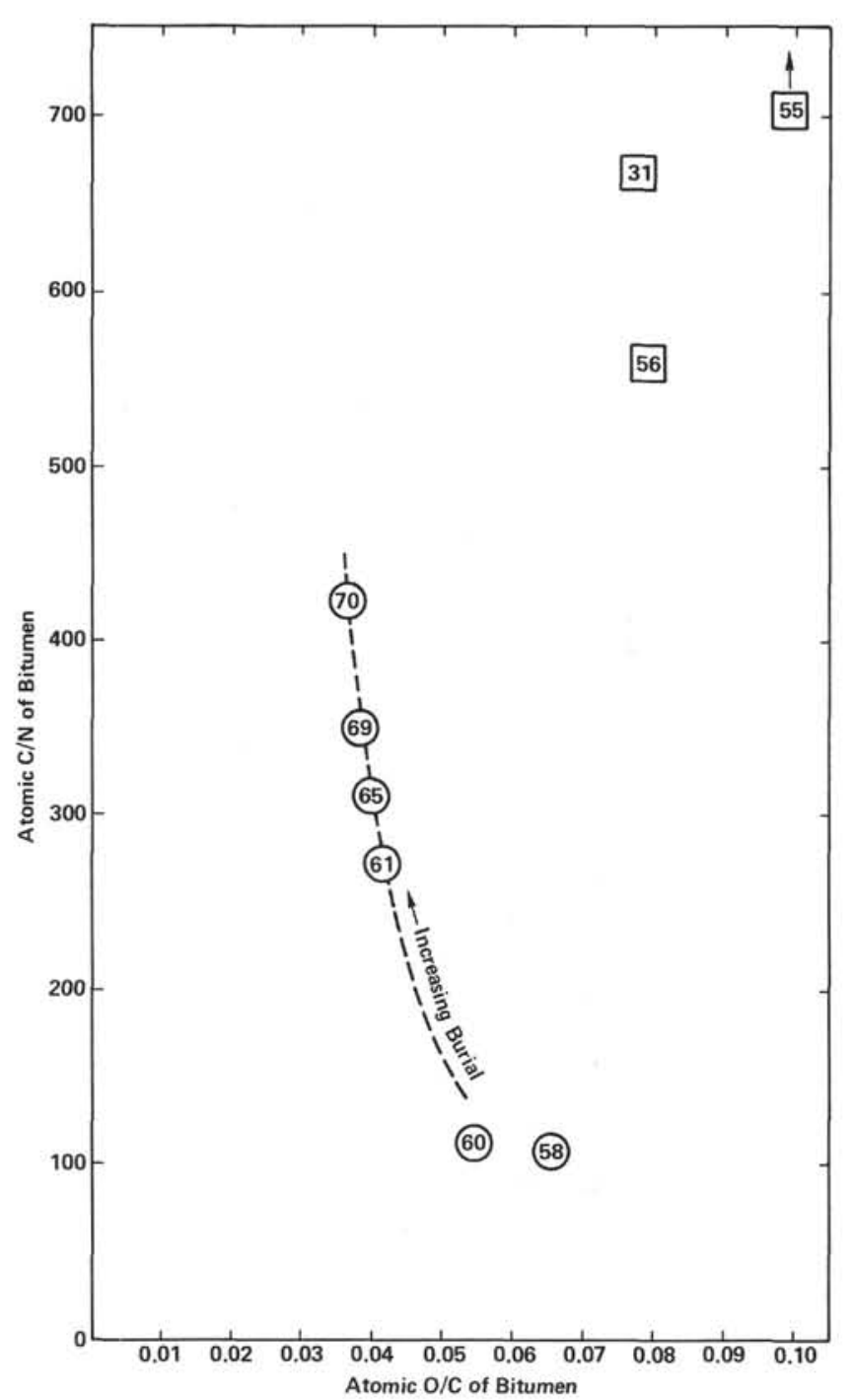

Figure 9. Atomic $\mathrm{O} / \mathrm{C}$ and $\mathrm{C} / \mathrm{N}$ ratios of bitumen (organic extracts) of some sediment samples from DSDP Site 511. The samples of the black shales facies (circles) show much lower $\mathrm{O} / \mathrm{C}$ and $\mathrm{C} / \mathrm{N}$ ratios (also depending on diagenesis) compared with the samples containing a residual type of organic matter (squares). (Samples are identified by core numbers; for full identification see Table 1.)

ing deposition in a wide range of water depths, from shallow to about 3000 meters (Thiede and van Andel, 1977).

Palynological and geological arguments (Harris, 1977; Shipboard Scientific Party et al., 1977) suggest a predrift position of the eastern part of the Falkland Plateau (Maurice Ewing Bank) close to the Mozambique Ridge. Thus there should be a correlation between the shales of the Plateau and equivalent shales from DSDP Site 361 (marginal Cape Basin). The lower Albian(?) and Aptian sapropelic shales at Site 361 (Unit 7, Site 361 ; Bolli et al., 1978) comprise more than 300 meters of sediments. Thus, at Site 361 much more sediment was accumulated during the Early Cretaceous than the extrapolated total sequence of about 200 meters of Aptian-Barremian (or older?) age at Site 511. However, the typical black shale layers at Site 361 average only 20

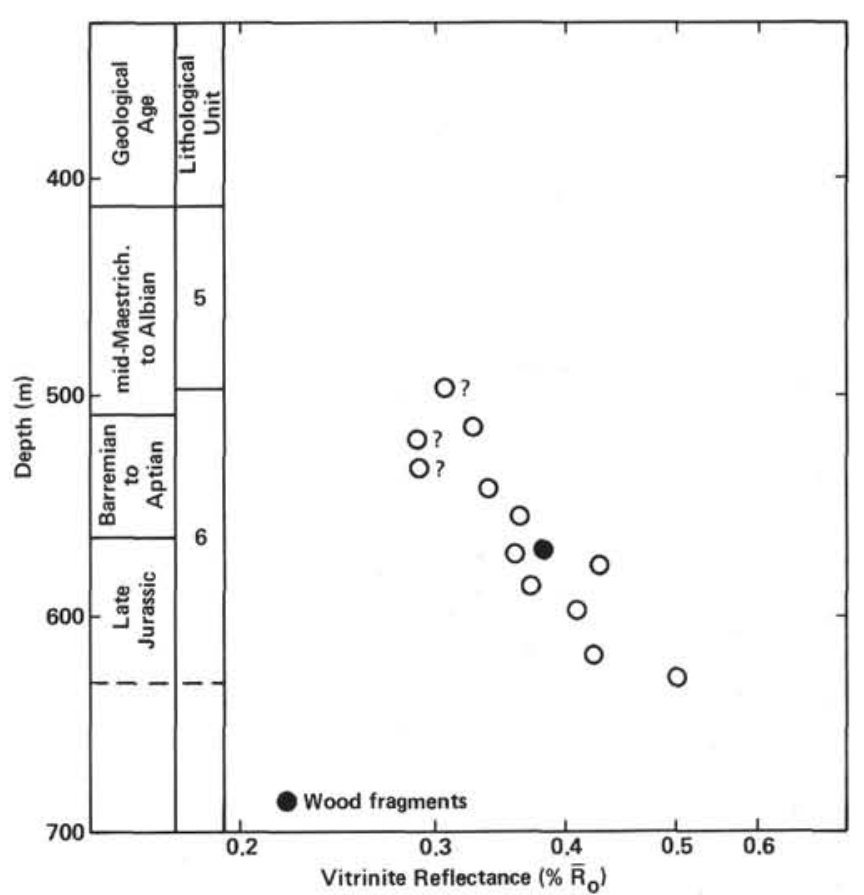

Figure 10. Mean vitrinite reflectance plotted as a function of depth. Although there seems to be a trend, its validity over such a short depth interval is questionable. Bituminous organic matter is supposed to have affected the reflectance values, especially in the shallower black shale samples.

$\mathrm{cm}$ each in thickness and are interbedded by massive silty and sandy layers and coarse (turbiditic) coaly sandstones. Kagami (1978) calculated $24 \%$ of Unit 7 from Site 361 to be black shales.

In addition to strata dominated by a marine type of organic matter (Tissot et al., 1980), terrigenous plant detritus forms an important or even the main portion of the organic fraction of the sediments at Site 361 (Raynaud and Robert, 1979). A similarly wide variety of kerogen types has been determined in young sediments from the Gulf of California (DSDP Leg 64; Rullkötter et al., in press). Site 361 and the Gulf of California Sites $474,478,479$, and 481 were, and still are, situated in narrow, rifting basins of at least partly anoxic waters reaching more than 3000 meters in depth (Thiede and van Andel, 1977). They then, as now, accumulated large masses of inorganic and organic detritus from the adjacent continents.

This is different from the situation on the Early Cretaceous Falkland Plateau. On the Plateau, which acted as a southern barrier in the spreading early South Atlantic, the black shales were deposited at shallow water depths. They do not occur in layers interbedded with many silty and sandy deposits but as a massive sequence of dark-colored, mostly black clays and mudstones. Except for the transitional zone, fewer than $3 \%$ of 145 samples analyzed by Deroo et al. (this volume) and us over a cored interval 120 meters long contain less than $1 \%$ of organic carbon. A predominantly marine source of organic matter has been determined for the majority of these samples. 
Table 5. Levels of organic maturation and temperature realms in three sedimentary basins. ${ }^{a}$

\begin{tabular}{|c|c|c|c|c|c|}
\hline Sedimentary Province & Geological Age & $\begin{array}{l}\text { Depth at Which } \\
0.45 \% \bar{R}_{0} \text { Level } \\
\text { is Reached } \\
\text { (m) }\end{array}$ & $\begin{array}{c}\text { Present } \\
\text { Temperature } \\
\left({ }^{\circ} \mathrm{C} \text { at }\right. \\
0.45 \% \text { 政 Level }\end{array}$ & $\begin{array}{l}\text { Present } \\
\text { Temperature } \\
\left({ }^{\circ} \mathrm{C} / \mathrm{km}\right)\end{array}$ & $\begin{array}{l}\text { Calculated } \\
\text { Paleotemperature } \\
\text { Gradient } \\
\left({ }^{\circ} \mathrm{C} / \mathrm{km}\right)\end{array}$ \\
\hline $\begin{array}{l}\text { Northwest African } \\
\text { Continental Rise: } \\
\text { DSDP Site } 397\end{array}$ & Early Cretaceous & 1450 & 62 & 42 & No data \\
\hline $\begin{array}{l}\text { Rhine Valley, West Germany: } \\
\text { Landau } 2 \text { borehole }\end{array}$ & Tertiary & 1100 & No data & 77 & $\begin{array}{l}58 \text { ( } 45 \text { for } \\
\text { Neogene, } 70 \\
\text { for Palaeogene) }\end{array}$ \\
\hline $\begin{array}{l}\text { Falkland Plateau: } \\
\text { DSDP Site } 511\end{array}$ & $\begin{array}{l}\text { Late Jurassic- } \\
\text { Early Cretaceous }\end{array}$ & 630 & 48 & 70 & $\begin{array}{l}<100 \\
\geq 70\end{array}$ \\
\hline
\end{tabular}

${ }^{a}$ Data from Teichmüller and Teichmüller (1979), Espitalié (1979), and Buntebarth (1979) for Landau 2 borehole, and from Cornford et al. (1979) for DSDP Site 397.

Several basins and basement highs separated the Falkland Plateau from the South African continent in predrift times (Jones and Plafker, 1977; Thompson, 1977). When the rift basin developed during Late Jurassic times, West Gondwana broke up and the masses of continental runoff originating from southern Africa were captured mainly in the spreading basin. This led to a reduced but more homogeneously distributed terrigenous input of prograded upslope sedimentation in the eastern part of the basin province of the Plateau. If the Maurice Ewing Bank in the northeast formed an emerged microcontinent at that time, as suggested by Ludiwig (this volume), a part of the inorganic and organic debris deposited at Site 511 probably also originates from that eastern part of the Falkland Plateau. The influx of terrigenous plant debris decreased as the spreading proceeded during the Early Cretaceous and the Plateau subsided.

The preservation of high amounts of autochthonous organic matter in a thick section of black shales can be related to very strong reducing conditions during deposition at shallow water depths. A strong mid-water oxygen minimum layer, originating from respiration and oxidation of organic material produced in surface waters, was likely to be well established. The change from reducing to oxic conditions on the Maurice Ewing Bank occurred at a time corresponding to the transitional zone near the Albian/Aptian boundary. At Site 361, this important change in environmental conditions is indicated by the lithologic change from Unit 7 to Unit 6 (Natland, 1978), which occurred either simultaneously with that of Site 511 or somewhat later in the lower Albian (the Aptian/Albian boundary is not definitively identified at Site 361; Bolli et al., 1978).

Thus, it seems plausible that euxinic conditions developed within the early basins of the South Atlantic, starting from a strong mid-water oxygen minimum layer and proceeding downward to deep bottom water. This ended at the moment the Plateau subsided and/or when a deep seaway between the Indian and Atlantic oceans was established, improving the water circulation. First indications of this change are already discernible within a transitional zone in the late Aptian, where the organic carbon content drops to moderate values and liptinites are presumably affected by oxidation. The bituminous organic matter originating from marine precursor organisms is an abundant constituent of the Aptian and Barremian black shales. As a consequence of the devel- opment of a better-ventilated, oxygenated system, the bituminous matter disappears within the "transitional zone," since marine organic matter is very sensitive to oxidation (Lyons and Gaudette, 1979). Thus, only liptinitic debris (apparently affected by oxidation) but no bituminites are left in Core 57 (early Albian). During Albian and post-Albian times, only small amounts of a refractory, residual type of organic matter were able to survive under the highly oxidizing conditions. This residual type of organic matter, originating mainly from continental runoff, can be traced along all cored sections of Site 511. Within the black shales, the autochthonous marine organic material is superimposed upon this refractory matter.

With respect to the potential for generating hydrocarbon at elevated temperatures, the Upper Jurassic and Lower Cretaceous shales are excellent hydrocarbon source rocks. In contrast, the Upper Cretaceous and Tertiary sediments have no potential for hydrocarbon generation-neither oil nor gas.

Given the vitrinite reflectance of $0.4-0.5 \% \overline{\mathrm{R}}_{0}$ at a bottom-hole depth of 632 meters and the downhole trend of several geochemical parameters, the onset of oil generation can be expected in depths slightly deeper than terminal depth at Hole 511, provided that potential Jurassic source rocks occur. Considering the present shallow depth of burial, the shales appear to be rather mature. Despite the present high thermal gradient $\left(7^{\circ} \mathrm{C} /\right.$ $100 \mathrm{~m}$ ), either a higher paleothermal gradient (up to $10^{\circ} \mathrm{C} / 100 \mathrm{~m}$ ), an additional overburden in the past above the unconformity (up to $400 \mathrm{~m}$ ), or a combination of both is required to explain the observed maturity. The heat flow measured at Site 511 is higher than in average oceanic basins and surprisingly high for old basement crust. It is not yet clear whether the "overmaturity" observed for both Sites 330 and 511 is due to a local heating event or is characteristic of larger areas on the Falkland Plateau. On the basis of theoretical considerations, Royden et al. (1980) predicted a vitrinite reflectance of $0.5 \% \overline{\mathrm{R}}_{0}$ at a sub-bottom depth of 3100 meters for the basin province of the Falkland Plateau. This maturity level at such a great depth of burial would imply an extremely low heat flow over geological times and is in extreme contrast with the measured results of Site 330 and 511. Although a local heating cannot be excluded for these sites, the vitrinite reflectance predicted by Royden et al. (1980) at that depth appears erroneously low. 


\section{ACKNOWLEDGMENTS}

We would like to thank I. Schwartz, U. Disko, and S. Huhn for technical assistance and Dr. H. Gormly for Rock-Eval pyrolysis data. Our thanks go to Dr. G. Deroo (Institut Français du Pétrole, Paris, France) and Dr. C. Cornford (British National Oil Corporation, Glasgow, United Kingdom) for carefully reading and reviewing the final manuscript and to Dr. H. W. Hagemann (Technische-Hochschule Aachen) for constructive criticism.

Samples were made available through the participation of the Deutsche Forschungsgemeinschaft (DFG) in the DSDP/IPOD program. This is gratefully acknowledged, as also is financial support by the DFG, grants No. We $346 / 23$ and We $346 / 24$. Hans von der Dick extends thanks to the Organic Geochemistry Panel of JOIDES, which made it possible for him to participate on Leg 71 .

\section{REFERENCES}

Bartenstein, H., and Teichmüller, R., 1974. Inkohlungsuntersuchungen, ein Schlussel zur Prospektierung von palaozoischen Kohlenwasserstoff-Lagerstatten? Fortschr. Geol. Rheinld. Westfalen, 24: 129-160.

Bolli, H. M., Ryan, W. B. F., and the Shipboard Scientific Party, 1978. Cape Basin continental rise-Sites 360 and 361 . In Bolli, H. M., Ryan, W. B. F., et al., Init. Repts. DSDP, 40: Washington (U.S. Govt. Printing Office), 29-182.

Bostick, N. H., and Alpern, B., 1977. Principles of sampling, preparation and constituent selection for microphotometry in measurement of maturation of sedimentary organic matter. J. Microscopy, 109(Pt. 1):41-47.

Buntebarth, G., 1979. Eine empirische Methode zur Berechnung von palaogeothermischen Gradienten aus dem Inkohlungsgrad organischer Einlagerungen in Sedimentgesteinen mit Anwendung auf den mittleren Oberrhein-Graben. Fortschr. Geol. Rheinld. Westfalen, 27:97-108.

Burke, R. A., Jr., Brooks, J. M., and Sackett, W. M., 1981. Light hydrocarbons in Red Sea brines and sediments. Geochim. Cosmochim. Acta, 45:627-634.

Comer, J. B., and Littlejohn, R., 1977. Content, composition and thermal history of organic matter in mesozoic sediments, Falkland Plateau. In Barker, P. F., Dalziel, I. W. D., et al., Init. Repts. DSDP, 36: Washington (U.S. Govt. Printing Office), 941-944.

Connan, J., 1974. Time-temperature relation in oil genesis. Bull. Am. Assoc. Pet. Geol., 58:2516-2521.

Cornford, C., Rullkötter, J., and Welte, D., 1979. Organic geochemistry of DSDP Leg 47A, Site 397 eastern North Atlantic: Organic petrography and extractable hydrocarbons. In von Rad, U., Ryan, W. B. F., et al., Init. Repts. DSDP, 47, Pt. 1: Washington (U.S. Govt. Printing Office), 511-522.

Espitalié, J., 1979. Charakterisierung der organischen Substanz und ihres Reifegrades in vier Bohrungen des mittleren OberrheinGrabens sowie Abschatzung der palaogeothermischen Gradienten. Fortschr. Geol. Rheinld. Westfalen, 27:87-96.

Espitalié, J., Laporte, J. L., Madec, M., Marquis, F., Leplat, P., Paulet, J., and Boutefeu, A., 1977. Methode rapide de caracterisation des roches-meres, de leur potential petrolier et de leur degre d'evolution. Rev. Inst. Fr. Pet., 32:23-42.

Harris, W. K., 1977. Palynology of cores from Deep Sea Drilling Project Sites 327, 328, and 330, South Atlantic Ocean. In Barker, P. F., Dalziel, I. W. D., et al., Init. Repts. DSDP, 36: Washington (U.S. Govt. Printing Office), 761-815.

Hunt, J. M., 1979. Petroleum Geochemistry and Geology: San Francisco (Freeman and Company).

Hutton, A. C., and Cook, A. C., 1980. Influence of alginite on the reflectance of vitrinite from Joadja, NSW, and some other coals and oil shales containing alginite. Fuel, 59:711-714.

Jacob, H,, 1980. Die Anwendung der Mikrophotometrie in der organischen Petrologie. Leitz-Mitt. Wiss. Techn., 7:209-216.

Jones, D. L., and Plafker, G., 1977. Mesozoic megafossils from DSDP Hole 327A and Site 330 on the eastern Falkland Plateau. In
Barker, P. F., Dalziel, I. W. D., et al., Init. Repts. DSDP, 36: Washington (U.S. Govt. Printing Office), 845-850.

Kagami, H., 1978. Sedimentary features of Cape Basin and Angola Basin sediments, DSDP Leg 40. In Bolli, H. M, Ryan, W. B. F., et al., Init. Repts. DSDP, 40: Washington (U.S. Govt. Printing Office), 525-540.

Lyons, W. B., and Gaudette, H. E., 1979. Sulfate reduction and the nature of organic matter in estuarine sediments. Org. Geochem., $1: 151-159$.

Natland, J. H., 1978. Composition, provenance, and diagenesis of Cretaceous clastic sediments drilled on the Atlantic continental rise off southern Africa, DSDP Site 361-implications for the early circulation of the South Atlantic. In Bolli, H. M., Ryan, W. B. F., et al., Init. Repts. DSDP, 40: Washington (U.S. Govt. Printing Office), 1025-1061.

Ourisson, G., Albrecht, P., and Rohmer, M., 1979. The hopanoids. Pure Appl. Chem., 51:709-729.

Raynaud, J. F., and Robert, P., 1979. Microscopical survey of organic matter from DSDP Sites 361, 362, and 364. In Bolli, H. M., Ryan, W. B. F., et al., Init. Repts. DSDP, Suppl. to Vols. 38, 39, 40, and 41: Washington (U.S. Govt. Printing Office), 663-669.

Reyment, R. A., 1980. Paleo-oceanology and paleo-biogeography of the Cretaceous South Atlantic Ocean. Oceanol. Acta, 3:127-133.

Royden, L., Sclater, J. G., and Von Herzen, R. P., 1980. Continental margin subsidence and heat flow: Important parameters in formation of petroleum hydrocarbons. Bull. Am. Assoc. Pet. Geol., 64: 173-187.

Rubinstein, I., Sieskind, O., and Albrecht, P., 1975. Rearranged sterenes in a shale: Occurrence and simulated formation. J. Chem. Soc. Perkin Trans. 1, (No. 19):1833-1836.

Rullkötter, J., von der Dick, H., and Welte, D. H., 1981. Organic petrography and extractable hydrocarbons of sediments from the eastern North Pacific Ocean, Deep Sea Drilling Project Leg 63. In Yeats, R. S., Haq, B. U., et al., Init. Repts. DSDP, 63: Washington (U.S. Govt. Printing Office), 819-836.

in press. Organic petrography and extractable hydrocarbons of sediments from the Gulf of California, Deep Sea Drilling Project Leg 64. In Curray, J. R., Moore, D. G, et al., Init. Repts. DSDP, 64: Washington (U.S. Govt. Printing Office).

Shipboard Scientific Party, Harris, W., and Sliter, W. V., 1977. Evolution of the southwestern Atlantic Ocean basin: Results of Leg 36, Deep Sea Drilling Project. In Barker, P. F., Dalziel, I. W. D., et al., Init. Repts. DSDP, 36: Washington (U.S. Govt. Printing Office), 993-1013.

Teichmüller, M., and Teichmüller, R., 1979. Diagenesis of coal (coalification). In Larsen, G., and Chilingar, G. V. (Eds.), Developments in Sedimentology, 25A: New York (Elsevier).

Thiede, J., and van Andel, Tj. H., 1977. The paleoenvironment of anaerobic sediments in the late Mesozoic South Atlantic Ocean. Earth Planet. Sci. Lett., 33:301-309.

Thompson, R. W., 1977. Mesozoic sedimentation on the eastern Falkland Plateau. In Barker, P. F., Dalziel, I. W. D., et al., Init. Repts. DSDP, 36: Washington (U.S. Govt. Printing Office), 877-891.

Tissot, B., Demaison, G., Masson, P., Delteil, J. R., and Combaz, A., 1980. Paleoenvironment and petroleum potential of middle Cretaceous black shales in Atlantic basins. Bull. Am. Assoc. Pet. Geol., 64:2051-2063.

Tissot, B., Deroo, G., and Herbin, J. P., 1979. Organic matter in Cretaceous sediments of the North Atlantic: Contribution to sedimentology and paleogeography. In Talwani, M., Hay, W., and Ryan, W. B. F. (Eds.), Deep Drilling Results in the Atlantic Ocean: Continental Margins and Paleoenvironment. Am. Geophys. Union, Maurice Ewing Series 3:362-374.

Van Dorsselaer, A., Albrecht, P., and Ourisson, G., 1977. Identification of novel $(17 \alpha \mathrm{H})$-hopanes in shales, coals, lignites, sediment and petroleum. Bull. Soc. Chim. Fr., pp. 165-170.

Waples, D. W., 1977. C/N ratios in source rock studies. Colo. Sch. Mines Miner. Ind. Bull., 20:1-7.

Wright, N. J. R., 1980. Time, temperature and organic maturationthe evolution of rank within a sedimentary pile. J. Pet. Geol., 2:411-425. 
APPENDIX

Compound Structures<smiles>[R]C(CCC(C)C1=C2CCC3C(CC[C@@]4(C)CCCCC34)C2(C)CC1)C(C)C</smiles>

I, rearranged sterenes

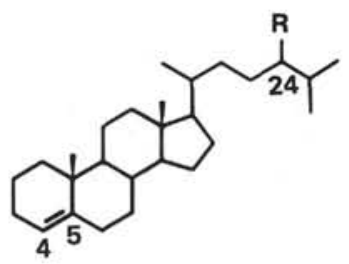

IV, ster-4-enes

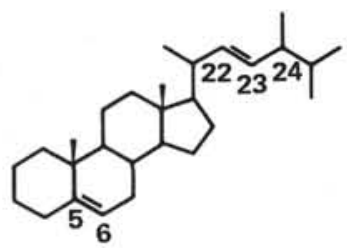

VII, 24-methylcholesta-5, 22-diene

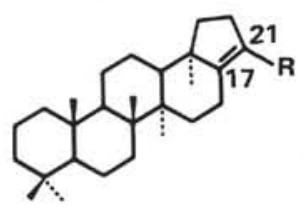

$X$, hop-17 (21)-enes

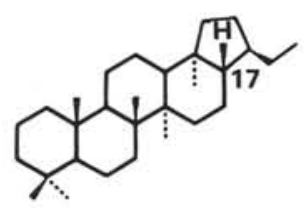

XIII, 30-normoretane

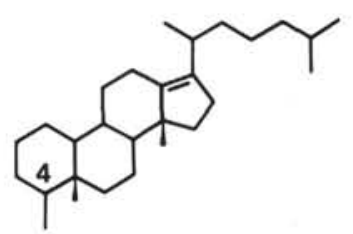

II, 4-methyl rearranged sterene<smiles>[R]C(C)C(C)CCC(C)C1CCC2C3CCCCC34CCCCC4CCC12C</smiles>

V, ster-5-enes<smiles>[R]C(CCC(C)C1CCC2C3CC[C@@H]4CCCC[C@]4(C)C3CCC12C)C(C)C</smiles>

VIII, steranes

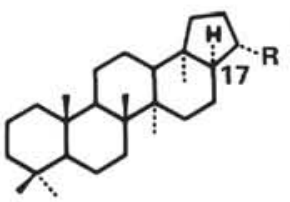

$\mathrm{XI}, 17 a(\mathrm{H})$-hopanes

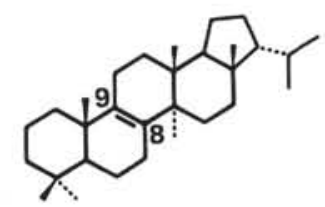

XIV, fern-8-ene<smiles>CC(C)CCCC(C)C1CCC2C3CCC4CC#CCC4(C)C3CCC12C</smiles>

III, cholest-2-ene

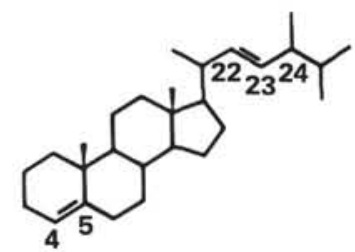

VI, 24-methylcholesta-4, 22-diene

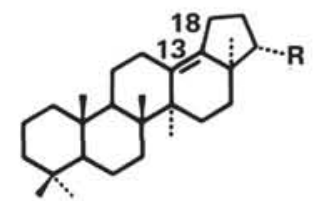

IX, neohop-13 (18)-enes

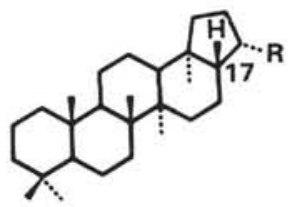

$X I I, 17 \beta(H)$-hopanes

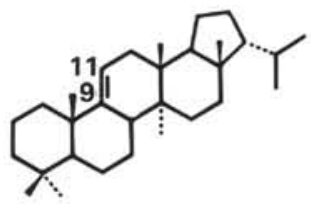

XV, fern-9 (11)-ene<smiles>CC(C)CCCC(C)CCCC(C)CCCC(C)CCCCC(C)CCCC(C)CCCC(C)CCCC(C)CCCC(C)C</smiles>

XVI, lycopane 